OPEN ACCESS

Edited by:

Micha Horacek

Josephinum Research, Austria

Reviewed by:

Marco lammarino, Istituto Zooprofilattico Sperimentale di

Puglia e Basilicata (IZSPB), Italy

Sandra Pati,

University of Foggia, Italy

Maria V. Baroni,

National University of

Cordoba, Argentina

${ }^{*}$ Correspondence:

Renata Leder

renata.leder@hapih.hr

Specialty section:

This article was submitted to

Food Chemistry,

a section of the journal

Frontiers in Nutrition

Received: 03 November 2020

Accepted: 07 January 2021

Published: 04 March 2021

Citation:

Leder R, Petric IV, Jusup J and

Banović M (2021) Geographical

Discrimination of Croatian Wines by

Stable Isotope Ratios and

Multielemental Composition Analysis.

Front. Nutr. 8:625613.

doi: 10.3389/fnut.2021.625613

\section{Geographical Discrimination of Croatian Wines by Stable Isotope Ratios and Multielemental Composition Analysis}

\author{
Renata Leder ${ }^{1 *}$, Ivana Vladimira Petric ${ }^{2}$, Josipa Jusup ${ }^{3}$ and Mara Banović ${ }^{4}$ \\ ${ }^{1}$ Department of Physico-Chemical Testing, Center for Viticulture, Enology and Edible Oils Analysis, Croatian Agency for \\ Agriculture and Food, Zagreb, Croatia, ${ }^{2}$ Department for Authentic Products, Center for Viticulture, Enology and Edible Oils \\ Analysis, Croatian Agency for Agriculture and Food, Zagreb, Croatia, ${ }^{3}$ Primevigilance d.o.o., Zagreb, Croatia, ${ }^{4}$ Department \\ of Food Engineering, Faculty of Food Technology and Biotechnology, University of Zagreb, Zagreb, Croatia
}

The $\delta^{18} \mathrm{O}$ and $\delta^{13} \mathrm{C}$ (analyzed by isotope ratio mass spectrometry, IRMS) and concentration of 22 selected elements (analyzed by inductively coupled plasma-optical emission spectrometry, ICP-OES) in 190 Croatian microvinified and commercial wine samples from continental and coastal winegrowing areas and from three viticultural zones $(\mathrm{B}, \mathrm{Cl}$, and $\mathrm{ClI})$ were measured to investigate whether multivariate statistical methods could provide the fingerprint for geographical origin determination. The highest power for discrimination of wines produced in Croatian winegrowing areas was achieved by general discriminant analysis (GDA) showing correct classification of $97.9 \%$ of all investigated samples, $100.0 \%$ of microvinified samples and $84.8 \%$ of commercial samples in the cross-validation matrix. The most significant markers for discrimination of coastal and continental areas found by GDA were $\delta^{18} \mathrm{O}$ and $\mathrm{Co}$, followed by $\mathrm{K}, \mathrm{Rb}, \mathrm{Sn}$, $\mathrm{Li}$, and $\delta^{13} \mathrm{C}$ in descending order. GDA showed higher levels of correctly classified samples from three viticultural zones in Croatia if only microvinified samples were employed in the analysis (94.9\%) than for all samples together (86.3\%) or for commercial samples $(66.1 \%)$ in the cross-validation matrix. The discrimination of viticultural zones $\mathrm{B}, \mathrm{Cl}$, and $\mathrm{Cll}$ in Croatia was achieved by $\delta^{18} \mathrm{O}$, Co, Rb, Li, K, and Sn. The results obtained showed that the relationships between the isotopic ratios and concentrations of different considered elements combined with appropriate statistical model represent a powerful tool in discrimination of wines produced in different Croatian winegrowing areas.

Keywords: Croatian wines fingerprint, elements, geographical origin, inductively coupled plasma optical emission spectroscopy, isotope ratio mass spectrometry, stable isotopes

\section{INTRODUCTION}

The adulteration of food and beverages is a growing global problem. Consumer awareness of the food safety importance has been steadily increasing in recent years as well as activities that include adulteration of food products for economic gain $(1,2)$. Following these trends, analytical methods for determination of the authenticity of food products, including wine, are also constantly being developed and upgraded accordingly $(3,4)$. Appropriate chemometric analysis of the data provided by those methods are needed and proposed for wine (5-7) and other food types, i.e., honey (8), 
cheese (9), and meat (10). Authenticity and commercial value of wine are often associated with geographical origin, and some countries or regions are known for producing high commercial value wines (3). Wine is a product that is often adulterated by the addition of sugar and/or water, as well as through intentional mislabeling of origin for economic gain $(6,11,12)$. Hence, the use of analytical methods to verify the declared composition and origin is of high-interest both for wine producers and consumers $(13,14)$. This is also increasingly recognized in Croatia (15-19), where viticulture and winemaking represent a significant economic activity, especially through the growing tourism industry (20).

The relationship between the isotope data of wine and physical variables related to the climate and geography of the production area is a very interesting topic, as is evident in many published papers in the last 20 years $(5,11,21-28)$.

Just like the stable isotopes, mineral elements are also considered to be good indicators of geographical origin of wine since they are neither metabolized nor modified during the wine production (29). Distinction of wine region through trace element composition is due to their close connection with their transfer from rock to soil and from soil to grape. The multi-element composition of wine is strongly influenced by the solubility of inorganic compounds in the soil and, in principle, the multielement composition of wine reflects the soil geochemistry of the grape growing region (30). Recent research has been conducted to determine the geographic origin based on the composition of the elements assuming that the chemical composition of the wine reflects the soil composition (31), in which case their determination enables the establishment of a "fingerprint" for each element and creates the possibility of establishing a link between wine and their geographical origin (26). The potential of multielement "fingerprint" techniques to identify the geographical origin of wine was established in many investigations in different countries: Portugal $(32,33)$, Italy (34, 35), Slovakia (36), Croatia (37, 38), Spain (39-41), Romania (42), Cyprus (7, 14), Slovenia (4), Serbia (43), Macedonia (44), Ukraine (45), Turkey (46), Argentina (47), South Africa (31, 48, 49), and California (50), USA.

Numerous researchers applied combined isotopic and multielement methods to determine the geographical origin of wine. One of the oldest such studies was carried out on French wines from the Bordeaux region (51). The characterization of Swiss vineyards using isotope data in combination with trace elements and classical parameters has also demonstrated the possibilities of multidimensional statistical data processing (52). IRMS, ICP-OES, and NMR analysis of authentic wines that are part of a Cypriot bank of authentic wines as well as analysis of Cypriot commercial wines have been carried out and the observed variations in isotopes and elements were compared with grape varieties, environmental conditions, and geographical origin $(7,14)$. The possibilities of isotope and multielement techniques as "fingerprints" have been explored in regional differentiation of Romanian wines for 2 years of harvest and various autochthonous and introduced varieties (53). The differentiation of wine samples from the border areas of Austria, Czech Republic, Slovakia (and from Serbia) was investigated by applying different techniques (e.g., IRMS, NMR, ICP-MS, ICPOES, EPR, HPLC, UV-VIS, etc.) showing promising possibilities for provenance studies (54).

Research to determine the geographical origin of wine has not only been conducted in Europe. Articles published by Argentine (55), Brazilian (56), Chinese (57), and American (58) authors are also available in the scientific literature. The most important conclusion of these studies is that the combined application of isotopic and multi-element methods with multivariate statistical methods will provide a promising statistical model for the classification of wines with regards to their geographical origin.

There are few published studies on determining the geographical origin of Croatian wines with regard to isotopic data (24), elemental profiles $(37,38,59)$, or some other aspects of wine quality, i.e., polyphenolic composition (17). Present work is the first study to combine isotopic and multielemental methods for discrimination of Croatian wines according to their geographical origin.

The geographic position of Croatia is a meeting point of a continental climate in the eastern and central parts of the country, and the Mediterranean climate in the southern, coastal areas. It is divided into three viticulture climate zones (B, CI, and CII; Figure 1) according to the Winkler (60) division system and into four winegrowing regions or geographical indications (61), which include 16 protected denominations of origin (PDO) registered at database for EU geographical indications eAmbrosia (62).

Temperature based bioclimatic Winkler index (WI) uses a growing degree base of $10^{\circ} \mathrm{C}$ (growing degree-days, GDD) and correlate viticulture with the climate through five viticulture regions (60). Accordingly, zone B (1391-1670 GDD or WI Region II) corresponds to the wine region of Croatian Uplands. The zone CI (1671-1940 GDD or WI Region III) appertains to the wine region of Slavonia and Croatian Danube. Zone CII (1941-2220 GDD or WI Region IV)

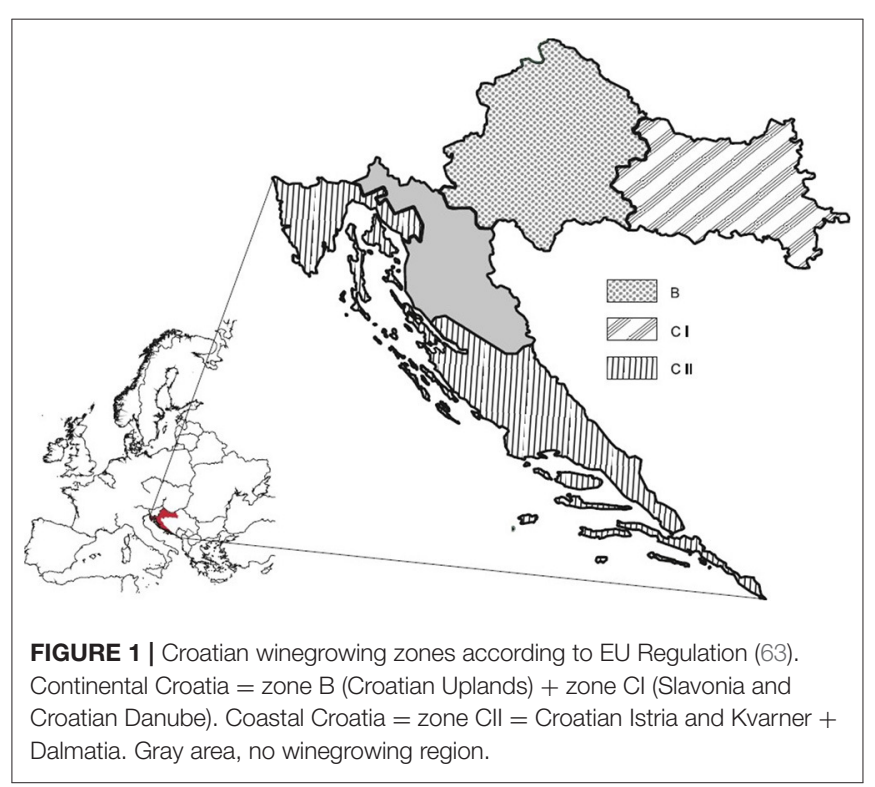


includes two wine regions: Croatian Istria and Kvarner, and Dalmatia.

Croatia joined the EU in 2013 and consequently participates in the EU Wine Isotopic Databank in order to comply with EU legislation $(64,65)$. Following these requirements, we produced and analyzed microvinified wines that are a part of the Croatian national and EU Wine Databank bank as well as commercial wines from Croatian wine producing regions. $\delta^{18} \mathrm{O}$ of wine water and $\delta^{13} \mathrm{C}$ of wine ethanol were determined by Isotope Ratio Mass Spectrometry (IRMS) and concentrations of $\mathrm{Al}, \mathrm{As}, \mathrm{B}, \mathrm{Ba}, \mathrm{Ca}, \mathrm{Cd}, \mathrm{Co}, \mathrm{Cr}, \mathrm{Cu}, \mathrm{Fe}, \mathrm{K}$, $\mathrm{Li}, \mathrm{Mg}, \mathrm{Mn}, \mathrm{Mo}, \mathrm{Na}, \mathrm{Pb}, \mathrm{Rb}, \mathrm{Sn}, \mathrm{Sr}, \mathrm{V}$, and $\mathrm{Zn}$ by Inductively Coupled Plasma-Optical Emission Spectrometry (ICP-OES). The aim of this study was to evaluate the obtained isotopic and multielement data by appropriate statistical methods in order to identify suitable geographical origin markers of Croatian wines and to obtain a chemometric tool for discrimination of wines produced in different Croatian winegrowing areas and zones.

\section{MATERIALS AND METHODS}

\section{Wine Samples}

One-hundred and ninety wines of two vintages (2015 and 2016) were analyzed. In total, 78 samples were a part of the Croatian bank of authentic wines produced by microvinification in accordance to the EU legislation (65), and 112 wines were conventionally produced and obtained by the Croatian Agency for Agriculture and Food, Center for Viticulture, Enology, and Edible Oils Analysis after the procedure of placing the wine on the Croatian market. Both indigenous and international white and red vine varieties were represented among the samples. The majority of these wines were monovarietal and evaluated as top quality after physicochemical analysis and sensory evaluation. The following parameters were determined: relative density, alcoholic strength, total dry extract, reducing sugars, $\mathrm{pH}$, total acidity, volatile acidity, ash, free, and total sulfur dioxide. Obtained results were in accordance to the specifications of declared PDO registered at database for EU geographical indications eAmbrosia (62). The limits of tested parameters for Croatian top quality PDO wines listed in specifications are: alcoholic strength $\geq 8.5 \%(\mathrm{v} / \mathrm{v})$ for zone $\mathrm{B}$ wines, and $\geq 9.0 \%(\mathrm{v} / \mathrm{v})$ for the wines from CI and CII zones; reducing sugar-free extract $\geq 18,19$, and $20 \mathrm{~g} \mathrm{~L}^{-1}$ (for white, rose, and red wine, respectively); total acidity (as tartaric acid) > $3.5 \mathrm{~g} \mathrm{~L}^{-1}$; volatile acidity (as acetic acid) $\leq 1.1 \mathrm{~g} \mathrm{~L}^{-1}$ for white and $\leq 1.2 \mathrm{~g} \mathrm{~L}^{-1}$ for red wines; ash content $\geq 1.5,1.6$, and $1.8 \mathrm{~g} \mathrm{~L}^{-1}$ (for white, rose, and red wines, respectively). With regard to the aspect of food safety, it is important to emphasize that the concentration of $\mathrm{SO}_{2}$ in all samples did not exceed the limits: $150 \mathrm{mg} \mathrm{L}^{-1}$ for red and $200 \mathrm{mg} \mathrm{L}^{-1}$ for rose and white wines with the residual sugar content $\leq 5 \mathrm{~g} \mathrm{~L}^{-1}$; and $200 \mathrm{mg} \mathrm{L}^{-1}$ for red and $250 \mathrm{mg} \mathrm{L}^{-1}$ for rose and white wines with the residual sugar content $>5 \mathrm{~g} \mathrm{~L}^{-1}$. Details about the origin of wines according to the winegrowing areas, zones, regions, type of production, harvest, and varieties are given in Table 1.

\section{Sample Preparation for $\delta^{13} \mathrm{C}$ Measurement}

Determination of alcoholic strength of the wine samples was performed by electronic density meter coupled with near infrared spectrometer (DMA 4500 and Alcolyzer, Patent Anton Paar ${ }^{\circledR}$ (66); Anton Paar, Austria). Wine samples with a volume of $200 \mathrm{~mL}$ were distillated at ADCS-Automated Distillation Control System (Eurofins, Nantes, France), operated by the ADSC V1.1.9.0 software. Karl Fischer DL31 volumetric titrator (Mettler Toledo, Greifensee, Swizterland) operated by LabX light titration v2.6 software (Mettler Toledo, Greifensee, Swizterland) was used for the determination of the distillate water content (\% $\mathrm{w} / \mathrm{w})$ in all obtained distillates in order to calculate the alcoholic strength $(\% \mathrm{w} / \mathrm{w})$ and yield of each performed distillation. Eurokarl Windows v.1.0.0.0 software (Eurofins, Nantes, France) was used for transfer of the obtained alcoholic strength data to the ADSC V1.1.9.0 software (Eurofins, Nantes, France). Reagents used for the Karl-Fischer titration were Titrant 5, Solvent and $1 \%$ water standard for the standardization procedure of the solvent were obtained from Merck (Darmstadt, Germany). The requirements for the distillation procedure are described in the OIV method (OIV-MA-AS311-05:R2011) (67).

\section{Sample Preparation for ICP-OES Measurements}

Residue of wine after obtaining the ethanol for $\delta^{13} \mathrm{C}$ measurement by ADCS distillation was used as described by Miloš et al. (68). The residue was returned to its initial volume and diluted $1: 1$ by $2 \%(\mathrm{v} / \mathrm{v}) \mathrm{HNO}_{3}$.

\section{Sample Preparation for $\delta^{18} 0$ Measurement}

No sample preparation was required.

\section{ICP-OES Measurements}

The determination of 22 elements was conducted by 2000 Dual View Optima ICP-OES (Perkin Elmer, Shelton, Connecticut, USA) equipped with a Meinhard spray chamber (Meinhard, Golden, Colorado, USA), nebulizer, and peristaltic sample delivery system. The instrument was controlled by the ICP WinLab 1.35 Perkin Elmer software. The flow conditions for plasma gas, auxiliary gas, and nebulizer gas were $15.0 \mathrm{~L} \mathrm{~min}^{-1}$, $0.2 \mathrm{~L} \mathrm{~min}-1$, and $0.8 \mathrm{~L} \mathrm{~min}{ }^{-1}$, respectively. Radio frequency generator power was set at $1,300 \mathrm{~W}$. Samples were analyzed by calibration curve method including the internal standard. Operating conditions of the used method were previously published (69).

The $60 \%$ (v/v) ultrapure $\mathrm{HNO}_{3}$ (Merck, Darmstadt, Germany) was used diluted to $2 \%(\mathrm{v} / \mathrm{v})$ by ultrapure water (18 $\mathrm{M} \Omega \mathrm{cm}^{-1}$ resistivity, Simplicity, Millipore, Molsheim, France) and used as blank, to prepare appropriate stock and calibration solutions and to dilute the samples. A $1 \mathrm{~g} \mathrm{~L}^{-1}$ ICP grade standard solution of yttrium (Perkin Elmer, Waltham, Massachusetts, USA) was used as an internal standard at the concentration of $100 \mu \mathrm{g} \mathrm{L}^{-1}$. Multi-element standards were prepared in-house by mixing of certified, traceable, ICP grade single element standards: $1 \mathrm{~g} \mathrm{~L}^{-1}$ of B and $\mathrm{Cr}$ (Acros Organics, New Jersey, USA), As, $\mathrm{Ca}, \mathrm{Cd}, \mathrm{Mg}, \mathrm{Mo}, \mathrm{Na}, \mathrm{Pb}, \mathrm{Zn}$, and $10 \mathrm{~g} / \mathrm{L}$ of $\mathrm{K}$ (Perkin Elmer, Waltham, Massachusetts, SAD), $1 \mathrm{~g} \mathrm{~L}^{-1}$ of $\mathrm{Al}, \mathrm{Ba}, \mathrm{Co}, \mathrm{Cu}, \mathrm{Fe}$, 
TABLE 1 | Geographical areas, wine-growing zones, and regions, type of production (microvinified-A, commercial-C), harvest (2015 and 2016), and varieties (indigenous varieties are marked with an asterisk) of the investigated wine samples ( $\mathrm{n}=$ total number of samples).

\begin{tabular}{|c|c|c|c|c|c|}
\hline Area & \multicolumn{2}{|c|}{ Continental Croatia = (zone B + zone Cl $)$} & \multicolumn{2}{|c|}{ Coastal Croatia = zone CII } & $\Sigma n$ \\
\hline$n$ (Area) & \multicolumn{2}{|r|}{120} & \multicolumn{2}{|l|}{70} & 190 \\
\hline$n(\mathrm{~A})$ & \multicolumn{2}{|r|}{42} & \multicolumn{2}{|l|}{36} & 78 \\
\hline$n(\mathrm{C})$ & \multicolumn{2}{|r|}{78} & \multicolumn{2}{|l|}{34} & 112 \\
\hline$n(2015)$ & \multicolumn{2}{|r|}{53} & \multicolumn{2}{|l|}{38} & 91 \\
\hline$n(2016)$ & \multicolumn{2}{|r|}{67} & \multicolumn{2}{|l|}{32} & 99 \\
\hline Zone & B & Cl & \multicolumn{2}{|l|}{ ClI } & \\
\hline Region & Croatian Uplands & Slavonia and Croatian Danube & Croatian Istria and Kvarner & \multicolumn{2}{|l|}{ Dalmatia } \\
\hline$n$ (Region) & 78 & 42 & 29 & 41 & 190 \\
\hline$n(\mathrm{~A})$ & 25 & 17 & 13 & 23 & 78 \\
\hline$n(\mathrm{C})$ & 53 & 25 & 16 & 18 & 112 \\
\hline$n(2015)$ & 31 & 22 & 16 & 22 & 91 \\
\hline$n$ (2016) & 47 & 20 & 13 & 19 & 99 \\
\hline $\begin{array}{l}\text { White wine } \\
\text { varieties }(n)\end{array}$ & \multicolumn{2}{|c|}{$\begin{array}{l}\text { Chardonnay (9), Gewürztraminer } \\
\text { (3), Grüner Sylvaner (5), } \\
\text { Kraljevina* (1), Moscato Giallo } \\
\text { (1), Müller Thurgau (1), Pinot } \\
\text { Blanc (4), Pinot Gris (5), Riesling } \\
\text { Italico (47), Rhein Riesling (7), } \\
\text { Sauvignon Blanc (8), Škrlet* (2), } \\
\text { mixture of white varieties (1). }\end{array}$} & \multicolumn{2}{|c|}{$\begin{array}{l}\text { Bogdanuša* (1), Cetinka* (1), } \\
\text { Chardonnay (6), Malvazija } \\
\text { istarska* (8), Maraština* (1), } \\
\text { Moscato Giallo (1), Pošip bijeli* } \\
\text { (6), Vugava* (1), Žlahtina* (1). }\end{array}$} & 120 \\
\hline $\begin{array}{c}\text { Red wine } \\
\text { varieties }(n)\end{array}$ & \multicolumn{2}{|c|}{$\begin{array}{l}\text { Blaufränkisch (5), Cabernet } \\
\text { Sauvignon (8), Merlot (9), Pinot } \\
\text { Noir (1), Zweigelt (2), mixture of } \\
\text { red varieties (1). }\end{array}$} & \multicolumn{2}{|c|}{$\begin{array}{l}\text { Babić }^{\star}(1), \text { Cabernet Franc (1), } \\
\text { Cabernet Sauvignon (2), Merlot } \\
\text { (14) Plavac mali crni (23), } \\
\text { Plavina* (1), mixture of red } \\
\text { varieties (2). }\end{array}$} & 70 \\
\hline
\end{tabular}

Li, Mn, Rb, Sn, Sr, and V (Reagecon, Shannon, County Clare, Ireland). To eliminate potential contamination, all glassware, and polypropylene storage bottles were rinsed by $\mathrm{HNO}_{3}(2 \% \mathrm{v} / \mathrm{v})$, and three times by ultrapure water, and allowed to dry before use.

Calibration was performed for each element at appropriate level (Table 2) and limits of detection and quantification were calculated as well as the recovery and measurement uncertainty $(70,71)$. The control charts of the standard reference material were used through the study period to ensure the quality of measurement results.

\section{IRMS Measurements}

IRMS measurements were performed by IRMS Delta V Plus (Thermo Fischer Scientific, Bremen, Germany) coupled to Gasbench and Elemental Analyzer FlashEA 1112 Series, for $\delta^{18} \mathrm{O}$ and $\delta^{13} \mathrm{C}$ measurements, respectively. Instruments were controlled by the Isodat 3.0 software (Thermo Fischer Scientific, Bremen, Germany). The isotopic ratios of ${ }^{13} \mathrm{C} /{ }^{12} \mathrm{C}$ and ${ }^{18} \mathrm{O} /{ }^{16} \mathrm{O}$ are expressed in the delta notation, $\delta^{13} \mathrm{C}$ and $\delta^{18} \mathrm{O}$, respectively, as part per thousand (\%). Determination of stable isotope ratio of $\delta^{18} \mathrm{O}$ in wine water was performed as described in the OIV method (OIV-MA-AS2-12:R2009) (67) after equilibration with helium and $\mathrm{CO}_{2}$ mixture at $24 \pm 1^{\circ} \mathrm{C}$ for $24 \mathrm{~h}$. The samples were analyzed against in house reference material calibrated by the certified reference materials VSLAP2 and VSMOW2 obtained at International Atomic Agency, Vienna, Austria. Determination of stable isotope ratio of $\delta^{13} \mathrm{C}$ in obtained ethanol was performed as described in the OIV method (OIV-MA-AS31206:R2001) (67). The samples were measured against the certified reference material BCR-656 (Institute for Reference Materials and Measurements, Geel, Belgium). Chemicals used for filling the combustion reactor for conversion the sample ethanol in carbon dioxide were copper (II) oxide, silver cobaltous/cobaltic oxide, and chromic (III) oxide (Thermo Fischer Scientific, Bremen, Germany). The quality of measurement results was validated by control charts of appropriate reference materials, which were recorded during the study and confirmed by participating to the interlaboratory comparisons organized by Eurofins (Nantes Cedex, France). Satisfactory quality of isotope measurement results was confirmed by obtained $z$-scores $(-2.00 \leq z \leq$ 2.00). Both methods for isotopic measurements are accredited in accordance to HRN EN ISO/IEC 17025:2017 (72), which confirms laboratory ability to perform valid and comparable stable isotope results.

\section{Statistical Analysis}

Results of isotopic and elemental analyses were uploaded to the software package Statistica 10.0 (Statsoft, Tulsa, Oklahoma, USA) and evaluated by descriptive statistical analysis (average 
TABLE 2 | Ranges of calibration, limits of detection (LOD), and limits of quantification (LOQ) expressed as concentration in matrix, recovery (\%), and expanded measurement uncertainty (\%) for all elements.

\begin{tabular}{|c|c|c|c|c|c|}
\hline Element $(\gamma)$ & $\begin{array}{l}\text { Calibration } \\
\text { range }(\gamma)\end{array}$ & $\operatorname{LOD}(\gamma)$ & $\operatorname{LOQ}(\gamma)$ & $\begin{array}{c}\text { Recovery } \\
(\%)\end{array}$ & $\begin{array}{c}\text { Measurement uncertainty } \\
\text { U (\%) }\end{array}$ \\
\hline $\mathrm{Al}\left(\mathrm{mg} \mathrm{L}^{-1}\right)$ & $0.1-2.0$ & 0.0004 & 0.0015 & 93 & 5 \\
\hline As $\left(\mu g L^{-1}\right)$ & $15-300$ & 9 & 28 & 97 & 11 \\
\hline$B\left(m g L^{-1}\right)$ & $0.25-5.0$ & 0.001 & 0.002 & 94 & 12 \\
\hline $\mathrm{Ba}\left(\mathrm{mg} \mathrm{L}^{-1}\right)$ & $0.05-1.00$ & 0.00001 & 0.00005 & 99 & 5 \\
\hline $\mathrm{Ca}\left(\mathrm{mg} \mathrm{L}^{-1}\right)$ & $5.0-100.0$ & 0.004 & 0.014 & 101 & 15 \\
\hline $\mathrm{Cd}\left(\mu \mathrm{g} L^{-1}\right)$ & $1-20$ & 0.3 & 0.9 & 101 & 4 \\
\hline $\mathrm{Co}\left(\mu \mathrm{g} L^{-1}\right)$ & $0.5-10.0$ & 0.4 & 1.2 & 106 & 11 \\
\hline $\mathrm{Cr}\left(\mu \mathrm{g} \mathrm{L}^{-1}\right)$ & $0.5-10.0$ & 0.3 & 1.2 & 106 & 16 \\
\hline $\mathrm{Cu}\left(\mathrm{mg} \mathrm{L}^{-1}\right)$ & $0.05-1.00$ & 0.0004 & 0.0013 & 98 & 5 \\
\hline $\mathrm{Fe}\left(\mathrm{mg} \mathrm{L}^{-1}\right)$ & $0.5-10.0$ & 0.003 & 0.009 & 101 & 7 \\
\hline $\mathrm{K}\left(\mathrm{mg} \mathrm{L^{-1 }}\right)$ & $100-2,000$ & 0.05 & 0.16 & 106 & 8 \\
\hline $\mathrm{Li}\left(\mu \mathrm{g} \mathrm{L}^{-1}\right)$ & $1-20$ & 0.004 & 0.014 & 93 & 7 \\
\hline $\mathrm{Mg}\left(\mathrm{mg} \mathrm{L}^{-1}\right)$ & 5-100 & 0.002 & 0.005 & 99 & 7 \\
\hline$M n\left(m g L^{-1}\right)$ & $0.25-5.00$ & 0.00004 & 0.00014 & 101 & 6 \\
\hline $\mathrm{Mo}\left(\mu \mathrm{g} \mathrm{L}^{-1}\right)$ & $0.5-10$ & 0.1 & 0.2 & 107 & 33 \\
\hline $\mathrm{Na}\left(\mathrm{mg} \mathrm{L}^{-1}\right)$ & 1.0-20.0 & 0.00 & 0.01 & 98 & 7 \\
\hline $\mathrm{Pb}\left(\mu \mathrm{g} L^{-1}\right)$ & 15-300 & 5 & 16 & 101 & 5 \\
\hline $\mathrm{Rb}\left(\mathrm{mg} \mathrm{L}^{-1}\right)$ & $0.25-5.00$ & 0.0003 & 0.0009 & 96 & 9 \\
\hline $\operatorname{Sn}\left(\mu g L^{-1}\right)$ & $0.05-1.00$ & 0.004 & 0.012 & 99 & 5 \\
\hline $\mathrm{Sr}\left(\mathrm{mg} \mathrm{L}^{-1}\right)$ & $0.05-1.00$ & 0.000004 & 0.000014 & 100 & 7 \\
\hline $\mathrm{V}\left(\mu \mathrm{g} \mathrm{L}^{-1}\right)$ & $5-100$ & 0.3 & 1.1 & 107 & 8 \\
\hline $\mathrm{Zn}\left(\mathrm{mg} \mathrm{L}^{-1}\right)$ & $0.25-5.00$ & 0.0005 & 0.0018 & 101 & 7 \\
\hline
\end{tabular}

values and standard deviations) and General Linear ModelAnalysis of Variance (GLM-ANOVA) followed by post-hoc Tukey test and multivariate analysis methods. For statistical processing, elements with the values below the LOD were set to LOD/2 (73). Multivariate analysis was performed by principal component analysis (PCA) using the Unscrambler ${ }^{\circledR}$ software package, version 11.0 (CAMO AS, Norway) and general discriminant analysis (GDA) using the Statistica software package 10.0 (Statsoft, Tulsa, Oklahoma, USA). For visual presentation of results MS Excel ${ }^{\circledR}$ [Microsoft Office Professional Plus 2019, Microsoft Excel 2019 MSO (16.0.10354.20022)] was used.

\section{RESULTS}

All elements (Al, As, B, Ba, Ca, Cd, Co, Cr, Cu, Fe, K, Li, Mg, Mn, $\mathrm{Mo}, \mathrm{Na}, \mathrm{Pb}, \mathrm{Rb}, \mathrm{Sn}, \mathrm{Sr}, \mathrm{V}$, and $\mathrm{Zn}$ ) were analyzed by ICP-OES in appropriate linear calibration ranges $\left(\mu \mathrm{g} \mathrm{L}^{-1}\right.$ or $\mathrm{mg} \mathrm{L}^{-1}$ ), which are presented together with limits of detection (LOD), limits of quantification (LOQ), recovery (\%), and expanded measurement uncertainty (\%) in Table 2 . The achieved recovery was between 93\% (for $\mathrm{Al}$ and $\mathrm{Li}$ ) and 107\% (for Mo and V). Assessment of expanded measurement uncertainty (with the coverage factor of $k=2$, which gives a $95 \%$ confidence level for normal distribution) showed the highest expanded uncertainty for Mo (33\%) and the lowest expanded uncertainty for $\mathrm{Cd}(4 \%)$.

GLM-ANOVA showed the significant interaction effect of the harvest year $(F=10.535 ; p<0.001)$, type of production
$(F=15.553 ; p<0.001)$, and viticulture zone $(F=9.274 ; p<$ 0.001 ) on tested measurands (stable isotopes and elements). The effect of the type of production was significant for the harvest $(F=4.843 ; p<0.001)$ and viticulture zones $(F=2.133 ; p<$ 0.001 ), and also the mutual interaction of these three effects was significant $(F=1.709 ; p<0.005)$ indicating that these attributes were useful in characterizing the differences among the measured values in wines. The significance between the effects of harvest year and viticulture zones was not found.

The results of stable isotopes $\left(\delta^{18} \mathrm{O}\right.$ and $\left.\delta^{13} \mathrm{C}\right)$ and 22 elements measurements in a set of 190 Croatian wine samples are given in Table 3 according to the area of production (continental and coastal) and viticulture zones (B, CI, and CII) in Croatia, together with the GLM-ANOVA and post-hoc Tukey test results. The measurands with important significance found by GLMANOVA $(p<0.05)$ for the type of production (microvinified vs. commercial), harvest year (2015 vs. 2016), area (continental vs. coastal), viticulture zones B vs. CI, B vs. CII, and CI vs. CII are marked by numbers from 1 to 6 , respectively. The average values of measured stable isotopes $\delta^{18} \mathrm{O}$ and $\delta^{13} \mathrm{C}$ were $1.37 \pm$ $2.56 \%$ SMOW and $-27.57 \pm 1.47 \%$ V-PDB, respectively. The ICP-OES analyses results showed that Croatian wines contain elements that may contribute to the daily dietary intake of essential metals (i.e., copper, iron, and zinc) but can also have potentially toxic effects if metal concentrations are not kept under allowable limits. Analyzed wines contain also elements that have no nutritional value but are known to be potentially toxic, like 
TABLE 3 | Summary of results (average values with standard deviations) for all measurands and samples according to the area of production (continental and coastal Croatia) and winegrowing zones (B, Cl, and CII) in Croatia.

\begin{tabular}{|c|c|c|c|c|c|c|}
\hline $\begin{array}{l}\text { Measurand } \\
\text { (Unit) }\end{array}$ & $\begin{array}{c}\text { GLM-ANOVA } \\
(p<0.05)^{\mathrm{a}}\end{array}$ & $\begin{array}{l}\text { All samples } \\
\qquad(n=190)\end{array}$ & $\begin{array}{l}\text { Continental Croatia } \\
=\text { Zone B + Zone Cl } \\
(n=120)\end{array}$ & $\begin{array}{l}\text { Coastal Croatia } \\
=\text { Zone CII } \\
(n=70)\end{array}$ & $\begin{array}{l}\text { Zone B } \\
(n=78)\end{array}$ & $\begin{array}{l}\text { Zone Cl } \\
(n=42)\end{array}$ \\
\hline$\delta^{18} \mathrm{O}(\%$ SMOW $)$ & $1,2,3,4,5,6$ & $1.37 \pm 2.56$ & $-0.22 \pm 1.47$ & $4.09 \pm 1.52$ & $-0.61 \pm 1.44$ & $0.51 \pm 1.23$ \\
\hline$\delta^{13} \mathrm{C}(\%$ V-PDB) & $2,3,5,6$ & $-27.57 \pm 1.47$ & $-28.31 \pm 1.01$ & $-26.29 \pm 1.24$ & $-28.38 \pm 0.99$ & $-28.20 \pm 1.06$ \\
\hline $\mathrm{Al}\left(\mathrm{mg} \mathrm{L}^{-1}\right)$ & $1,3,5$ & $0.59 \pm 0.52$ & $0.51 \pm 0.42$ & $0.74 \pm 0.64$ & $0.48 \pm 0.39$ & $0.56 \pm 0.48$ \\
\hline As $\left(\mu g L^{-1}\right)$ & & $7.5 \pm 5.4$ & $7.2 \pm 5.1$ & $8.2 \pm 5.9$ & $7.2 \pm 5.0$ & $7.2 \pm 5.2$ \\
\hline$B\left(m g L^{-1}\right)$ & $1,3,5,6$ & $2.98 \pm 1.14$ & $2.62 \pm 1.03$ & $3.60 \pm 1.07$ & $2.76 \pm 0.97$ & $2.36 \pm 1.10$ \\
\hline $\mathrm{Ba}\left(\mathrm{mg} \mathrm{L}^{-1}\right)$ & 6 & $0.11 \pm 0.05$ & $0.11 \pm 0.05$ & $0.10 \pm 0.04$ & $0.11 \pm 0.05$ & $0.12 \pm 0.04$ \\
\hline $\mathrm{Ca}\left(\mathrm{mg} \mathrm{L}^{-1}\right)$ & $1,2,3,5$ & $85.0 \pm 22.7$ & $89.3 \pm 21.2$ & $77.5 \pm 23.6$ & $92.1 \pm 20.9$ & $84.1 \pm 20.9$ \\
\hline $\mathrm{Cd}\left(\mu \mathrm{g} L^{-1}\right)$ & 2 & $0.7 \pm 1.0$ & $0.7 \pm 1.0$ & $0.8 \pm 0.8$ & $0.7 \pm 1.2$ & $0.5 \pm 0.7$ \\
\hline Co $\left(\mu g L^{-1}\right)$ & 2 & $5.9 \pm 4.4$ & $5.5 \pm 3.9$ & $6.6 \pm 5.1$ & $5.8 \pm 4.4$ & $4.9 \pm 2.6$ \\
\hline $\operatorname{Cr}\left(\mu g L^{-1}\right)$ & 2 & $19.0 \pm 17.0$ & $17.4 \pm 12.0$ & $21.8 \pm 23.1$ & $17.4 \pm 11.8$ & $17.4 \pm 12.6$ \\
\hline $\mathrm{Cu}\left(\mathrm{mg} \mathrm{L}^{-1}\right)$ & & $0.18 \pm 0.14$ & $0.17 \pm 0.15$ & $0.18 \pm 0.12$ & $0.18 \pm 0.17$ & $0.16 \pm 0.09$ \\
\hline $\mathrm{Fe}\left(\mathrm{mg} \mathrm{L}^{-1}\right)$ & 1 & $1.91 \pm 1.39$ & $1.86 \pm 1.43$ & $20.1 \pm 1.34$ & $1.78 \pm 1.32$ & $2.00 \pm 1.61$ \\
\hline $\mathrm{K}\left(\mathrm{mg} \mathrm{L} \mathrm{L}^{-1}\right)$ & $3,5,6$ & $788 \pm 226$ & $730 \pm 180$ & $889 \pm 260$ & $730 \pm 179$ & $730 \pm 185$ \\
\hline $\mathrm{Li}\left(\mu \mathrm{g} \mathrm{L}^{-1}\right)$ & 3,6 & $4.6 \pm 3.2$ & $5.2 \pm 3.5$ & $3.6 \pm 2.3$ & $4.7 \pm 3.3$ & $6.0 \pm 3.6$ \\
\hline $\mathrm{Mg}\left(\mathrm{mg} \mathrm{L}^{-1}\right)$ & $1,4,5$ & $81.3 \pm 17.9$ & $79.8 \pm 16.6$ & $83.9 \pm 19.8$ & $76.8 \pm 15.9$ & $85.4 \pm 16.5$ \\
\hline $\mathrm{Mn}\left(\mathrm{mg} \mathrm{L}^{-1}\right)$ & 4,6 & $0.96 \pm 0.52$ & $1.01 \pm 0.58$ & $0.87 \pm 0.39$ & $0.92 \pm 0.63$ & $1.19 \pm 0.45$ \\
\hline Mo $\left(\mu g L^{-1}\right)$ & 2 & $4.3 \pm 2.1$ & $4.4 \pm 2.2$ & $4.1 \pm 2.0$ & $4.7 \pm 2.3$ & $4.0 \pm 2.0$ \\
\hline $\mathrm{Na}\left(\mathrm{mg} \mathrm{L}^{-1}\right)$ & $1,3,5,6$ & $14.3 \pm 18.1$ & $10.6 \pm 7.0$ & $20.8 \pm 27.3$ & $10.7 \pm 7.9$ & $10.2 \pm 5.0$ \\
\hline $\mathrm{Pb}\left(\mu \mathrm{g} \mathrm{L}^{-1}\right)$ & $1,2,3$ & $30.2 \pm 18.7$ & $28.0 \pm 17.2$ & $33.8 \pm 20.5$ & $29.1 \pm 16.5$ & $26.1 \pm 18.6$ \\
\hline $\mathrm{Rb}\left(\mathrm{mg} \mathrm{L}^{-1}\right)$ & $3,5,6$ & $1.08 \pm 0.41$ & $0.99 \pm 0.42$ & $1.22 \pm 0.35$ & $1.05 \pm 0.43$ & $0.88 \pm 0.37$ \\
\hline $\operatorname{Sn}\left(\mu g \mathrm{~L}^{-1}\right)$ & $2,3,5,6$ & $55.0 \pm 30.3$ & $48.4 \pm 31.1$ & $66.3 \pm 25.3$ & $46.8 \pm 29.2$ & $51.6 \pm 34.6$ \\
\hline $\operatorname{Sr}\left(\mathrm{mg} \mathrm{L}^{-1}\right)$ & 1 & $0.46 \pm 0.21$ & $0.46 \pm 0.17$ & $0.46 \pm 0.28$ & $0.46 \pm 0.18$ & $0.45 \pm 0.15$ \\
\hline$\vee\left(\mu g L^{-1}\right)$ & 1 & $83.6 \pm 16.8$ & $82.4 \pm 15.8$ & $85.6 \pm 18.3$ & $80.0 \pm 15.1$ & $86.7 \pm 16.2$ \\
\hline $\mathrm{Zn}\left(\mathrm{mg} \mathrm{L}^{-1}\right)$ & & $0.69 \pm 0.37$ & $0.67 \pm 0.32$ & $0.73 \pm 0.44$ & $0.69 \pm 0.34$ & $0.64 \pm 0.27$ \\
\hline
\end{tabular}

${ }^{a}$ Measurands with p < 0.05 for: (1) - type of production; (2) - harvest year; (3)-continental and coastal area; (4) -zones B and Cl; (5) - zones B and Cll; (6) -zones Cl and Cll.

arsenic, cadmium, and lead $(74,75)$. The results showed that the lowest concentration of all samples had the micro-elements $\mathrm{Cd}$ $\left(0.7 \pm 1 \mu \mathrm{g} \mathrm{L}^{-1}\right)$, Mo $\left(4 \pm 2 \mu \mathrm{g} \mathrm{L}^{-1}\right), \mathrm{Li}\left(5 \pm 3 \mu \mathrm{g} \mathrm{L}^{-1}\right)$, Co $(6 \pm 4$ $\left.\mu \mathrm{g} \mathrm{L}^{-1}\right)$, and As $\left(8 \pm 5 \mu \mathrm{g} \mathrm{L}^{-1}\right)$. The highest concentrations had the macro-elements $\mathrm{K}\left(788 \pm 226 \mathrm{mg} \mathrm{L}^{-1}\right), \mathrm{Ca}\left(85 \pm 23 \mathrm{mg} \mathrm{L}^{-1}\right)$, $\mathrm{Mg}\left(81 \pm 18 \mathrm{mg} \mathrm{L}^{-1}\right)$, and $\mathrm{Na}\left(14 \pm 18 \mathrm{mg} \mathrm{L}^{-1}\right)$. The determined concentrations of $\mathrm{As}, \mathrm{B}, \mathrm{Cd}, \mathrm{Cu}$, and $\mathrm{Pb}$ that are related to the safety of wines were within the acceptable limits established by the OIV-International Organization of Vine and Wine (76). Maximum permitted concentration $\left(80 \mathrm{mg} \mathrm{L}^{-1}\right)$ prescribed by the OIV was exceeded only for $\mathrm{Na}$ in three samples. The obtained results suggest that moderate consumption of Croatian wines may contribute to the daily dietary intake of essential minerals and trace elements without the danger of exceeding admissible daily dose or causing a toxic effect according to dietary reference values for nutrients of European Food Safety Authority (EFSA) (77).

A study of the data structure by PCA was carried out to aid in interpretation of the obtained data and to establish whether the wines from different wine producing geographical areas and viticulture zones constitute distinctive, well-defined groups. PCA was performed for all wines and variables (isotopes and elements) to determine whether different geographical regions of origin (areas and zones) had influenced the isotopes and elements profile. In this context, 2 isotopic ratios and 22 elements posed as the investigated variables, while wines posed as the cases under investigation.

PCA performed for entire dataset of microvinified and commercial wines $(n=190)$ is explaining only $65 \%$ of variability by first seven factors. The first two factors (PC1 and PC2) represent $29.2 \%$ of the initial data variability and $40 \%$ with the third factor (PC3). The remaining 25\% of significant variability is hidden in the remaining four factors (PC4-PC7). Total variability of the first seven factors and eigenvectors of correlation matrix for all samples obtained by PCA is shown in Table 4 .

The PCA model for entire data set was validated by segmented cross validation (random method, 20 segments, and 9 samples per segment) and significance of the variables ( $p$-value) was estimated by a $t$-test. Most of the measurands were found to be significant $(p<0.05)$ for the differentiation of the geographical origin according to the obtained $p$-values (Table 4). Only $\mathrm{Cu}$ and $\mathrm{Zn}$ showed no significance in either of PC1-PC7. Because the calibration set (the raw data set, $n=190$ ) explained only $65 \%$, and the validation set correctly explained only $39 \%$ of total variability for first seven PCs (Table 4), it was concluded that overall uncertainty of the model is fairly high. Hence, the 
TABLE 4 | Eigenvectors (EV) of correlation matrix for all samples ( $n=190$ ) obtained by PCA for first seven factors (PC1-PC7 with eigenvalues of correlation matrix > 1), total variability $\%$ for calibration set (TV), total variability \% obtained by cross validation (CV), and significance of the variables (highlighted are the $p<0.05$ ).

\begin{tabular}{|c|c|c|c|c|c|c|c|c|c|c|c|c|c|c|}
\hline & \multicolumn{2}{|c|}{ PC1 } & \multicolumn{2}{|c|}{ PC2 } & \multicolumn{2}{|c|}{ PC3 } & \multicolumn{2}{|c|}{ PC4 } & \multicolumn{2}{|c|}{ PC5 } & \multicolumn{2}{|c|}{ PC6 } & \multicolumn{2}{|c|}{ PC7 } \\
\hline TV (\%) & \multicolumn{2}{|c|}{15,64} & \multicolumn{2}{|c|}{13,52} & \multicolumn{2}{|c|}{10,87} & \multicolumn{2}{|c|}{7,43} & \multicolumn{2}{|c|}{6,41} & \multicolumn{2}{|c|}{5,82} & \multicolumn{2}{|c|}{5,15} \\
\hline CV (\%) & \multicolumn{2}{|c|}{7,90} & \multicolumn{2}{|c|}{10,19} & \multicolumn{2}{|c|}{7,61} & \multicolumn{2}{|c|}{3,59} & \multicolumn{2}{|c|}{1,62} & \multicolumn{2}{|c|}{3,09} & \multicolumn{2}{|c|}{4,63} \\
\hline Measurand & EV & $p$ & EV & $p$ & EV & $p$ & EV & $p$ & EV & $p$ & EV & $p$ & EV & $p$ \\
\hline${ }^{18} \mathrm{O} /{ }^{16} \mathrm{O}$ & 0.08 & 0.03 & 0.04 & 0.06 & -0.48 & 0.00 & -0.15 & 0.00 & 0.20 & 0.00 & 0.09 & 0.23 & -0.18 & 0.06 \\
\hline As & 0.08 & 0.09 & -0.01 & 0.71 & -0.08 & 0.02 & -0.18 & 0.02 & -0.26 & 0.00 & -0.26 & 0.02 & 0.58 & 0.00 \\
\hline$B$ & 0.04 & 0.03 & 0.23 & 0.00 & -0.29 & 0.00 & 0.10 & 0.00 & -0.31 & 0.00 & -0.31 & 0.00 & -0.12 & 0.05 \\
\hline $\mathrm{Ba}$ & 0.23 & 0.00 & 0.02 & 0.54 & 0.26 & 0.00 & -0.15 & 0.06 & 0.28 & 0.00 & -0.33 & 0.00 & -0.17 & 0.04 \\
\hline $\mathrm{Ca}$ & 0.11 & 0.01 & 0.24 & 0.00 & 0.27 & 0.00 & 0.24 & 0.00 & -0.28 & 0.00 & 0.02 & 0.82 & 0.07 & 0.38 \\
\hline $\mathrm{Cd}$ & 0.11 & 0.00 & -0.24 & 0.00 & -0.15 & 0.00 & 0.48 & 0.00 & 0.09 & 0.06 & -0.04 & 0.42 & 0.18 & 0.01 \\
\hline $\mathrm{Fe}$ & 0.13 & 0.05 & -0.25 & 0.00 & -0.07 & 0.30 & -0.17 & 0.17 & 0.21 & 0.12 & -0.03 & 0.86 & 0.18 & 0.49 \\
\hline K & 0.11 & 0.01 & 0.16 & 0.00 & -0.23 & 0.00 & 0.12 & 0.09 & -0.07 & 0.21 & -0.49 & 0.00 & 0.02 & 0.80 \\
\hline $\mathrm{Li}$ & 0.22 & 0.00 & -0.11 & 0.00 & 0.28 & 0.00 & -0.20 & 0.03 & 0.08 & 0.42 & -0.07 & 0.67 & -0.15 & 0.23 \\
\hline $\mathrm{Mg}$ & 0.28 & 0.00 & 0.34 & 0.00 & 0.03 & 0.13 & 0.19 & 0.00 & 0.24 & 0.00 & 0.09 & 0.04 & 0.11 & 0.16 \\
\hline $\mathrm{Mn}$ & 0.28 & 0.00 & 0.01 & 0.49 & 0.25 & 0.00 & -0.09 & 0.15 & 0.23 & 0.02 & -0.23 & 0.08 & -0.19 & 0.07 \\
\hline Mo & 0.24 & 0.00 & -0.21 & 0.00 & 0.06 & 0.15 & 0.33 & 0.00 & -0.26 & 0.00 & 0.06 & 0.23 & -0.07 & 0.45 \\
\hline $\mathrm{Na}$ & 0.29 & 0.03 & -0.02 & 0.59 & -0.11 & 0.04 & -0.27 & 0.12 & -0.20 & 0.30 & 0.28 & 0.22 & -0.02 & 0.88 \\
\hline $\mathrm{Pb}$ & 0.24 & 0.00 & -0.34 & 0.00 & -0.18 & 0.00 & 0.17 & 0.00 & 0.08 & 0.11 & 0.03 & 0.64 & 0.14 & 0.17 \\
\hline $\mathrm{Rb}$ & 0.03 & 0.53 & 0.18 & 0.00 & -0.14 & 0.01 & -0.19 & 0.04 & -0.19 & 0.10 & -0.36 & 0.01 & -0.22 & 0.14 \\
\hline Sn & 0.11 & 0.01 & 0.36 & 0.00 & -0.10 & 0.02 & -0.08 & 0.14 & 0.10 & 0.19 & 0.30 & 0.00 & 0.06 & 0.52 \\
\hline Sr & 0.30 & 0.00 & 0.19 & 0.00 & 0.09 & 0.18 & -0.01 & 0.92 & -0.15 & 0.14 & 0.10 & 0.27 & 0.12 & 0.23 \\
\hline
\end{tabular}

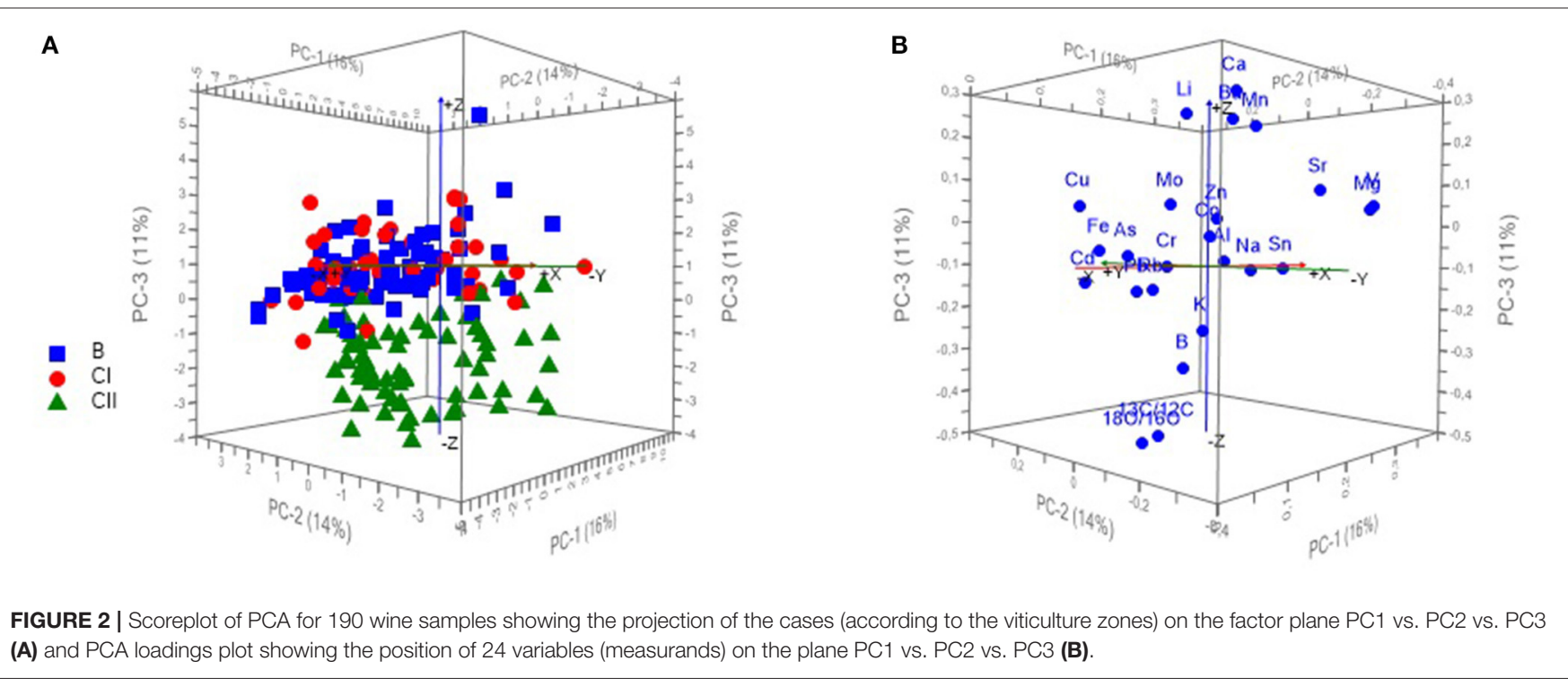



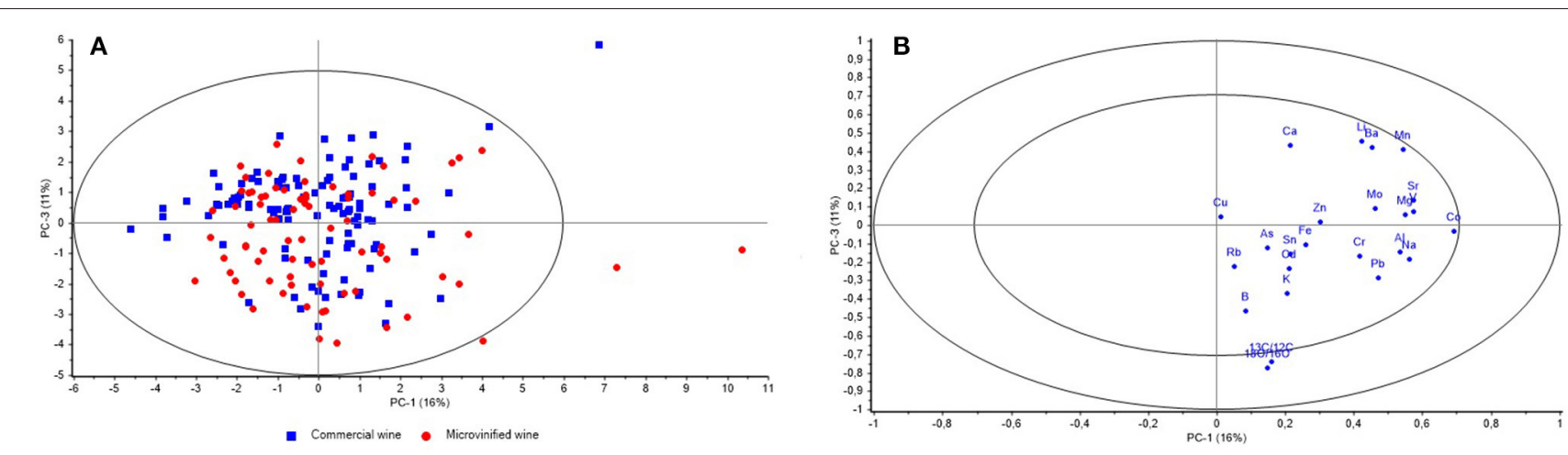

FIGURE 3 | Scoreplot of PCA for 78 samples of microvinified wines and 112 samples of commercial wines showing the projection of the cases (according to the type of production) on the factor plane PC1 vs. PC3 (A) and PCA correlation loadings plot showing the position of 24 variables (measurands) on the plane PC1 vs. PC3 (B).

additional statistical tool of multivariate analysis (GDA) needed to be applied.

Scoreplot of PCA for 190 wine samples is showing the projection of the cases (according to the viticulture zones) on the factor planes PC1 vs. PC2 vs. PC3 (Figure 2A), where wines from the continental part of Croatia (zones B and CI) are positioned mostly on the positive side of PC3 while the wines from coastal Croatia (zone CII) remained on the negative side of the PC3. Positioning of the variables on the factor planes PC1 vs. PC2 vs. PC3 can be observed at Figure 2B indicating the strongest influence of $\delta^{18} \mathrm{O}$ and $\delta^{13} \mathrm{C}$ on the grouping of the samples from coastal Croatia.

Since microvinified samples are part of the Croatian national isotope database of authentic wines, PCA was also carried out to visualize the effect of the type of production on the positioning of the samples on the factor planes in order to establish whether the microvinified wines can be used as a representative set for the authenticity evaluation of declared geographical origin of commercial wines by used set of variables (stable isotopes and elements). In addition to the entire data set, the PCA was also performed for microvinified and commercial wines separately. Eigenvalues of correlation matrix $(>1)$ showed that $76 \%$ of total variability is explained by the first eight factors for the microvinified, and $71 \%$ for commercial data set (Supplementary Table 1).

The scoreplot of PCA for microvinified wines and commercial wines (Figure 3A) is showing the projection of the cases according to the type of production on the factor plane PC1 vs. PC3 and with the $95 \%$ confidence interval. Rather uniform distribution of microvinified and commercial samples in the PC1 and PC3 planes can be observed, indicating the same effect of the measured values (stable isotopes and elements) influencing the distribution of the samples, both microvinified and commercial. Figure 3B is showing PCA correlation loadings plot with the position of 24 variables (measurands) in the plane PC1 vs. PC3 and the Hotelling's $\mathrm{T}^{2}$ ellipse representing 50 and $100 \%$ of modeled variance $\left(r^{2}\right.$ $=0.5 / 1)$. The highest effect on the variability explained by

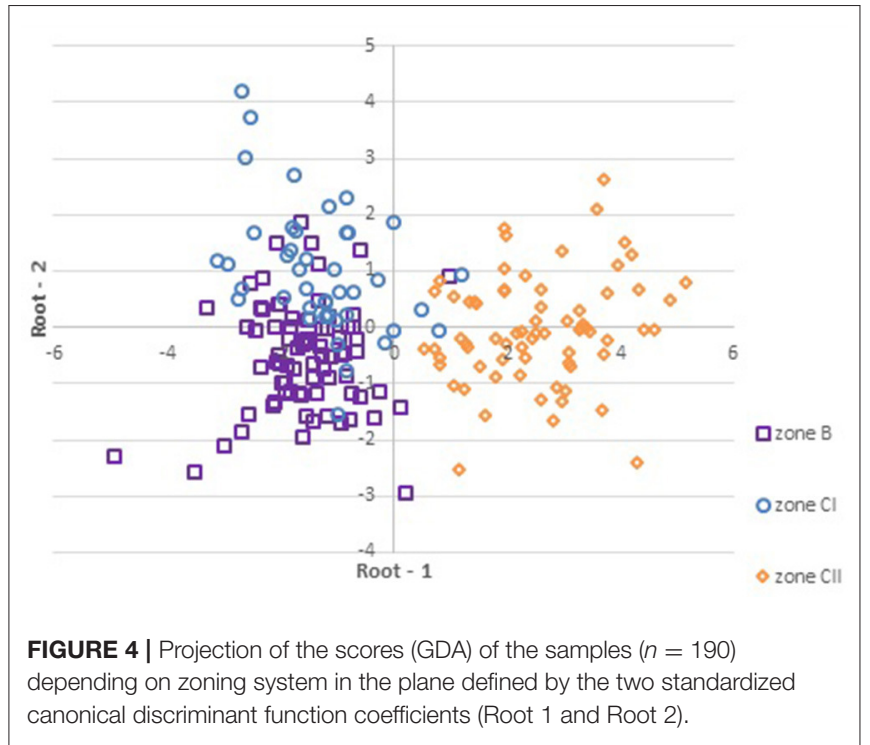

PC3 have variables $\delta^{18} \mathrm{O}$ and $\delta^{13} \mathrm{C}$ positioned between the two ellipses.

GDA analysis was performed to choose the variable with the most significant contribution to the discrimination between continental and coastal winegrowing areas of Croatia and then for the viticulture zones B, CI, and CII. The reduced number of variables was used based on the significance obtained by PCA ( $\mathrm{Cu}$ and $\mathrm{Zn}$ were omitted). Also, the model was validated through cross-validation using the set of microvinified wines as the model, and the set of commercial wines as unknown samples.

Figure 4 depicts the projection of the cases (zones) on the Root 1 vs. Root 2 where wines from the continental part of Croatia (zones B and CI) are positioned mostly on the negative side of root 1 while the wines from coastal Croatia (zone CII) remained on the positive side.

Multivariate test of significance (Wilks test, $p \leq 0.05$; Supplementary Table 2) showed that most significant for geographical areas discrimination (coastal and continental) are 
TABLE 5 | Classification matrix obtained by GDA showing the percentage of correctly predicted classifications (\%) vs. the observed classifications for continental and coastal winegrowing areas and zones $\mathrm{B}, \mathrm{Cl}$, and $\mathrm{Cll}$.

\begin{tabular}{lccc}
\hline $\begin{array}{l}\text { Winegrowing areas } \\
\text { and zones }\end{array}$ & $\begin{array}{c}\text { Complete } \\
\text { data } \\
\text { set (all } \\
\text { wines) } \\
(\boldsymbol{n}=\mathbf{1 9 0})\end{array}$ & $\begin{array}{c}\text { Authentic } \\
\text { wines } \\
(\boldsymbol{n}=\mathbf{7 8})\end{array}$ & $\begin{array}{c}\text { Crossvalidation } \\
\text { data set } \\
\text { (commercial } \\
\text { wines) } \\
(\boldsymbol{n}=\mathbf{1 1 2})\end{array}$ \\
\hline Continental Croatia & 97.5 & 100.0 & 87.2 \\
Coastal Croatia & 98.6 & 100.0 & 79.4 \\
\hline Total & $\mathbf{9 7 . 9}$ & $\mathbf{1 0 0 . 0}$ & $\mathbf{8 4 . 8}$ \\
\hline Zone Cll & 100.0 & 100.0 & 79.4 \\
Zone B & 91.0 & 96.0 & 67.9 \\
Zone Cl & 54.8 & 82.4 & 44.0 \\
\hline Total & $\mathbf{8 6 . 3}$ & $\mathbf{9 4 . 9}$ & $\mathbf{6 6 . 1}$ \\
\hline
\end{tabular}

$\delta^{18} \mathrm{O}$ and Co, followed by $\mathrm{K}, \mathrm{Rb}, \mathrm{Sn}, \mathrm{Li}$, and $\delta^{13} \mathrm{C}$, and for discrimination of samples according to the zones most significant are $\delta^{18} \mathrm{O}$ and $\mathrm{Co}$, followed by $\mathrm{Rb}, \mathrm{Li}, \mathrm{K}$, and $\mathrm{Sn}$, in descending order. Classification matrix obtained by GDA, showing the percentage of correctly predicted classifications (\%) vs. the observed classifications for continental and coastal winegrowing areas and zones $\mathrm{B}, \mathrm{CI}$, and CII, is shown in Table 5. In the entire dataset $(n=190)$ the GDA classification matrix correctly classified $97.9 \%$ of the samples in regards to the winegrowing areas, while for the microvinified and commercial wines, correct classification was achieved for 100.0 and $84.8 \%$ of the samples, respectively.

Regarding the three viticulture zones, $86.3 \%$ of correct classification was achieved for the entire dataset, while for the microvinified and commercial wines, correct classification was achieved for 94.9 and $66.1 \%$ of the samples, respectively.

Regarding the differentiation between two zones (B and CI) of the continental part of Croatia, which can also be observed at the Figure 4 to some extent, GDA showed correct classification for $67.9 \%$ of the samples from zone B and for only $44.0 \%$ of the samples from zone CI. Correct classification was obtained for $79.4 \%$ of the CII zone samples.

\section{DISCUSSION}

The isotopic and multielement composition of the analyzed wines and statistical methods were used as chemical descriptors in order to establish criteria for wine classification and differentiation according to geographical origin.

The measurands with important significance found by GLMANOVA $(p<0.05)$ and marked from 1 to 6 in Table 3 are herein discussed in more detail. Post-hoc test (Tukey test) was conducted to evaluate the significance of the influence of the type of sample production, vintages, and winegrowing areas (continental and coastal Croatia), and viticulture climate zones (B, CI, and CII) on the measurands.
GLM-ANOVA of obtained results for all samples in regards to the type of production (Table 3 , measurands denoted by 1 ) showed statistically significant differences between microvinified and commercial samples for $\delta^{18} \mathrm{O}, \mathrm{Al}, \mathrm{B}, \mathrm{Ca}, \mathrm{Fe}, \mathrm{Mg}, \mathrm{Na}$, $\mathrm{Pb}, \mathrm{Sr}$, and $\mathrm{V}$, which could be caused by oenological practices employed for production of commercial samples but lacking at the microvinification process, and by the differences in the size of actual samples (25 kg of grapes for microvinified vines). The $\delta^{18} \mathrm{O}$ values differences could also imply the mislabelling of the commercial samples in regard to the geographical origin or vintage, or possibility of water addition. Nevertheless, intensive rainfall during grape harvest also will be reflected in the isotope ratios values (13). To establish the possibility of fraudulent activities more elaborate investigation of isotopic ratios should be employed (23).

Regarding the harvest year (2015 and 2016), there were significant differences for $\delta^{18} \mathrm{O}, \delta^{13} \mathrm{C}, \mathrm{Ca}, \mathrm{Cd}, \mathrm{Co}, \mathrm{Cr}, \mathrm{Mo}, \mathrm{Pb}$, and Sn (Table 3, measurands denoted by 2), showing the contribution of the seasonal meteorological conditions influencing their uptake $(5,78) . \delta^{18} \mathrm{O}$ of water values were more positive (in average for 1\%o) in the 2015 than in the 2016 harvest. This can be explained by the higher rainfall in September during the 2016 harvest (average $152 \mathrm{~mm}$ ) (79) compared to the 2015 harvest (average $88 \mathrm{~mm}$ ) (80). Similar influence of rainfall on $\delta^{18} \mathrm{O}$ of wine water was observed by previous research $(13,56)$. Variations of $\delta^{13} \mathrm{C}$ can also be the result of plant growth conditions, which can significantly modify $13 \mathrm{C}$ isotope values (81), in particular, the use of $\mathrm{CO}_{2}$ from photorespiration by the plant that reacts to water deficit by closing the stomata (82).

Regardless of the studied vintage year or the type of production, the GLM-ANOVA of isotopic ratios and multielement content enabled the discrimination of the two studied winegrowing areas (continental and coastal Croatia) and three winegrowing zones (B, CI, and CII). The statistically significant discrimination of the continental and coastal winegrowing areas was achieved for the following measurands: $\delta^{18} \mathrm{O}, \delta^{13} \mathrm{C}, \mathrm{Al}, \mathrm{B}, \mathrm{Ca}, \mathrm{K}, \mathrm{Li}, \mathrm{Na}, \mathrm{Pb}, \mathrm{Rb}$, and $\mathrm{Sn}$ (Table 3, measurands denoted by 3 ). These measurands were also identified as the key explanatory factors in various combinations for geographical origin determination by other researches, i.e., for Spanish (40, 41), Italian (34, 35), Romanian $(53,83,84)$, Cypriot (7), USA (85), Brazilian (56), or Chinese (57) wines.

Wine samples from continental vineyards presented significantly lower average values of $\delta^{18} \mathrm{O}$ than those from coastal vineyards ( -0.2 and $4.1 \%$ SMOW, respectively). These differences between geographical areas can be explained by the specific climatic conditions of each individual area, such as temperature, humidity, as well as meteorological conditions. The mean values of $\delta^{18} \mathrm{O}$ found in this research are consistent to those obtained for Croatian wines of vintages 1999-2001 (24). Obtained $\delta^{18} \mathrm{O}$ values are also in accordance with the wines from different European regions (22). The range of $\delta^{13} \mathrm{C}$ values of wines from the two investigated geographical areas is variating from $-26.3 \%$ V-PDB in coastal part of Croatia to $-28.3 \%$ $\mathrm{V}$-PDB in continental area. The mean values of $\delta^{13} \mathrm{C}$ found in the present work are similar to those obtained by previous research $(22,24)$. 
Samples from the coastal Croatian vineyards had significantly higher content of $\mathrm{Al}, \mathrm{B}, \mathrm{K}, \mathrm{Na}, \mathrm{Pb}, \mathrm{Rb}$, and $\mathrm{Sn}$ than the continental vineyards. The values of $\mathrm{Na}$ were almost double in coastal $\left(21 \mathrm{mg} \mathrm{L}^{-1}\right)$ than in continental areas $\left(11 \mathrm{mg} \mathrm{L}^{-1}\right)$ due to the proximity of the Adriatic Sea. This influence of the sea on the elevated $\mathrm{Na}$ content was observed by other investigations $(7,86,87)$. As opposed to this, the continental vineyards were characterized by higher levels of $\mathrm{Ca}\left(89 \mathrm{mg} \mathrm{L}^{-1}\right)$ and $\mathrm{Li}(5 \mu \mathrm{g}$ $\left.\mathrm{L}^{-1}\right)$ than in coastal vineyards $\left(76 \mathrm{mg} \mathrm{L}^{-1}\right.$ of Ca and $4 \mu \mathrm{g} \mathrm{L}^{-1}$ of Li).

Statistically significant discrimination between two continental winegrowing zones B and CI is achieved only by the $\delta^{18} \mathrm{O}, \mathrm{Mg}$, and $\mathrm{Mn}$ (Table 3, measurands denoted by 4). As expected with regards to geographical and climatic conditions, average values of $\delta^{18} \mathrm{O}$ of wine water from the eastern continental part of Croatia (zone CI) were higher than those of the wines from vineyards in the western continental region of Croatia (zone B), 0.51 and $-0.61 \%$ SMOW, respectively. Both elements, the $\mathrm{Mg}$ and $\mathrm{Mn}$, had higher content in zone CI (85 and $77 \mathrm{mg} \mathrm{L}^{-1}$, respectively) than in zone $\mathrm{B}(1.2$ and $0.9 \mathrm{mg}$ $\mathrm{L}^{-1}$, respectively).

In regards to the differentiation of the coastal zone CII vs. continental zone B, significant were the same measurands (Table 3, measurands denoted by 5) as for entire costal vs. continental area, with the exception of $\mathrm{Pb}$ and the addition of $\mathrm{Mg}$, which was able to discriminate between zones CII and B (84 and $77 \mathrm{mg} \mathrm{L}^{-1}$, respectively).

$\delta^{18} \mathrm{O}, \delta^{13} \mathrm{C}, \mathrm{B}, \mathrm{Ba}, \mathrm{K}, \mathrm{Li}, \mathrm{Mn}, \mathrm{Na}, \mathrm{Rb}$, and $\mathrm{Sn}$ (Table 3, measurands denoted by 6 ) enabled the differentiation of the coastal zone CII vs. continental zone CI. Average values of element B were significantly higher in coastal zone CII $(3.6 \mathrm{mg}$ $\left.\mathrm{L}^{-1}\right)$ than in continental zone $\mathrm{CI}\left(2.4 \mathrm{mg} \mathrm{L}^{-1}\right.$ respectively). Ba was found to be significant only in discrimination of zones CI and CII, but it also enabled the geographical origin differentiation in the research of Croatian (37), Italian (35), Romanian (42), and South African (31) wines.

Compared to the PCA results for the entire data set, which explains $65 \%$ of the variability, the set of microvinified samples has a higher percentage of explained variability (75\%) and better presents the geographic origin than the whole data set (Supplementary Table 1). This difference can be explained by the fact that microvinified samples do not have the influence of elements from the production process, i.e., $\mathrm{Al}, \mathrm{B}, \mathrm{Cu}, \mathrm{K}, \mathrm{Fe}, \mathrm{Mn}$ (88-91). In these samples, the distinction of geographical origin is achieved only by endogenous measurands that reached the wine naturally, i.e., stable isotopes (5) or elements $\mathrm{Mg}$, $\operatorname{Sr}(57,88)$ and/or as natural contaminant such as $\mathrm{Na}$ (91). Even commercial samples evaluated separately by PCA have explained more variability (71\%) than the whole set (Supplementary Table 1). This can also be explained by the influence of a technological process that is more or less similar in all commercial samples. Hence, it can be concluded that the combination of samples of different types of production leads to less explained overall variability.

As seen at Figure 2A, the $3 \mathrm{D}$ representation of the samples obtained from PCA using the raw data matrix (190 samples and 24 measurands) and the first three components indicates a satisfactory separation of samples according to the geographical area, although the first three components explained only $40 \%$ of the total variation. The samples from continental Croatia (zone CII) are well-distinguished from the samples from coastal Croatia (zones B and CI). The differentiation of continental zones B and CI by PCA method was not achieved.

It is shown that $\delta^{18} \mathrm{O}$ and $\delta^{13} \mathrm{C}$ (Figure 2B) have the strongest influence on separation of the CII zone from B and CI zones in the plane PC1 vs. PC2 vs. PC3 (Figure 2A). The significance of this influence is also visible at the Figure $\mathbf{3 B}$, which is showing Hotelling's $\mathrm{T}^{2}$ ellipse representing 50 and $100 \%$ of modeled variance $\left(r^{2}=0.5 / 1\right)$. The highest effect on the variability explained by PC3 have variables $\delta^{18} \mathrm{O}$ and $\delta^{13} \mathrm{C}$ positioned between the two ellipses.

Overlapping of microvinified and commercial samples in the PC1 vs. PC3 planes (Figure 3A) is showing similar impact of the measured values on observed variability. This is an indication that the microvinified wines can be used as a representative set for the authenticity evaluation of declared geographical origin of commercial wines by used set of variables (stable isotopes and elements). However, the positioning of three microvinified samples from CII zone and one commercial sample from zone B outside of the $95 \%$ confidence interval can be noticed. This could be the result of specific microclimatic and pedologic characteristics of individual vineyards locations and it can be supported by the research of Croatian winegrowing regions (92) where it was found that both Western and Eastern continental Croatian regions, ranging from 1,323.9 to 1,652.5 GDD for the observed climatologic period (1988-2017) belong to the Winkler Regions I and II (zone A and B). In regards to Coastal Croatia in the same period, values ranged from $1,496.5$ to $2,483.5 \mathrm{GDD}$, which is Winkler Region II to $\mathrm{V}$ (zones B, CI, CII, and CIII). The reason for outlying of the commercial sample from the zone B should be explored in more detail, considering all relevant meteorological and winegrowing parameters such as precipitation, harvest date, grape variety, and to use a representative number of reference samples (23).

GDA was found to be the most distinguishing chemometric tool for discrimination of Croatian wines according to the area of geographical origin. As seen at Table 5, the highest power for discrimination of wines produced in coastal and continental Croatia showed GDA by correct classification $100.0 \%$ of microvinified samples, $97.9 \%$ of all investigated samples, and $84.8 \%$ of commercial samples in the crossvalidation matrix.

GDA showed somewhat weaker separation (Figure 4) of the zones $\mathrm{B}$ and $\mathrm{CI}$ in comparison to the excellent discrimination of continental and coastal areas. This can be explained by incompliance between official borders of the zones (Figure 1) (63) and actual situation presented by previous research (92), which established that within the zone B exist a smaller area corresponding to the Winkler Region I (zone A) and that Slavonia and Croatian Danube fall into Region II, which is zone B and not $\mathrm{CI}$ as stated by the current EU division system. 
This can explain the deviation of some samples outside of the designated zones in particular if taking into consideration that the most dominant marker of the geographical origin identified by this research is the $\delta^{18} \mathrm{O}$, which is also strongly influenced by the climate $(5,22)$.

The analysis of bioclimatic indices in Croatian winegrowing regions (92) would enable more accurate interpretation of isotopic and multielement data found in this research as the tools for Croatian wine geographical origin determination. Furthermore, current administrative division of the zones established by the EU legislation (63) is defining the limits and conditions for certain oenological practices (enrichment limits/increase in the natural alcoholic strength) where climatic conditions have made it necessary in certain winegrowing zones. Consequently, a question arises of interpreting the isotopic data from EU wine data bank in regards to chaptalization, requiring a larger number of representative samples and expert interpretation. The shortcomings of Croatian vineyards zoning are also suggested by projections of further warming and drying of the climate in Croatia (93), making the existing viticulture zoning even less adequate.

This study verified that stable isotopes of oxygen and carbon have proven to be most valuable indicators of discrimination of wines from Croatian winegrowing areas and zones and especially in the combination with the multielemental composition analysis, which was conducted here for the first time for Croatian wines.

Results suggest that the proposed methodology is a powerful tool and it could add extra value to local Croatian wines by emphasizing the wine authenticity importance, especially in the light of the growing tourism industry and increasing awareness of winemaking significance as economic activity.

\section{REFERENCES}

1. Bong Y-S, Shin W-J, Gautam MK, Jeong Y-J, Lee AR, Jang C-S, et al. Determining the geographical origin of Chinese cabbages using multielement composition and strontium isotope ratio analyses. Food Chem. (2012) 135:2666-74. doi: 10.1016/j.foodchem.2012.07.045

2. Chua LS, Abdul-Rahaman N-L, Sarmidi MR, Aziz R. Multielemental composition and physical properties of honey samples from Malaysia. Food Chem. (2012) 135:880-7. doi: 10.1016/j.foodchem.201 2.05.106

3. Luykx DMAM, van Ruth SM. An overview of analytical methods for determining the geographical origin of food products. Food Chem. (2008) 107:897-911. doi: 10.1016/j.foodchem.2007.09.038

4. Šelih VS, Šala M, Drgan V. Multi-element analysis of wines by ICPMS and ICP-OES and their classification according to geographical origin in Slovenia. Food Chem. (2014) 153:414-23. doi: 10.1016/j.foodchem.201 3.12.081

5. Camin F, Dordevic N, Wehrens R, Neteler M, Delucchi L, Postma $\mathrm{G}$, et al. Climatic and geographical dependence of the $\mathrm{H}, \mathrm{C}$ and $\mathrm{O}$ stable isotope ratios of Italian wine. Anal Chim Acta. (2015) 853:38490. doi: 10.1016/j.aca.2014.09.049

6. Dordevic N, Camin F, Marianella RM, Postma GJ, Buydens LMC, Wehrens R. Detecting the addition of sugar and water to wine. Aust J Grape Wine Res. (2013) 19:324-30. doi: 10.1111/ajgw.12043

7. Kokkinofta R, Fotakis C, Zervou M, Zoumpoulakis P, Savvidou $\mathrm{C}$, Poulli K, et al. Isotopic and elemental authenticity markers:

\section{DATA AVAILABILITY STATEMENT}

The raw data supporting the conclusions of this manuscript will be made available by the authors, without undue reservation, to any qualified researcher.

\section{AUTHOR CONTRIBUTIONS}

RL and MB: conceptualization. RL and IVP: methodology and writing-original draft preparation. JJ and RL: formal analysis and investigation. MB: writing-review and editing and supervision. All authors: contributed to the article and approved the submitted version.

\section{FUNDING}

This research was supported by the Center for Viticulture, Enology and Edible Oils Analysis, Croatian Agency for Agriculture and Food, Zagreb, Croatia.

\section{ACKNOWLEDGMENTS}

The authors would like to thank to the wine producers for the support of this study by donation of grapes for microvinification.

\section{SUPPLEMENTARY MATERIAL}

The Supplementary Material for this article can be found online at: https://www.frontiersin.org/articles/10.3389/fnut.2021. 625613/full\#supplementary-material

a case study on cypriot wines. Food Anal Methods.

(2017) 10:3902-13. doi: 10.1007/s12161-017-0959-2

8. Soares S, Amaral JS, Oliveira MBPP, Mafra I. A comprehensive review on the main honey authentication issues: production and origin. Comp Rev Food Sci Food Saf. (2017) 16:1072-100. doi: 10.1111/1541-4337. 12278

9. Vargas-Bello-Pérez E, Gómez-Cortés P, Geldsetzer-Mendoza C, Morales MS, Toro-Mujica P, Fellenberg MA, et al. Authentication of retail cheeses based on fatty acid composition and multivariate data analysis. Int Dairy J. (2018) 85:280-4. doi: 10.1016/j.idairyj.2018. 06.011

10. Miedico O, Iammarino $M$, Tarallo $M$, Chiaravalle AE. Application of inductively coupled plasma-mass spectrometry for trace element characterisation of equine meats. Int J Food Prop. (2017) 20:2888900. doi: 10.1080/10942912.2016.1256304

11. Geana EI, Popescu R, Costinel D, Dinca OR, Stefanescu I, Ionete RE, et al. Verifying the red wines adulteration through isotopic and chromatographic investigations coupled with multivariate statistic interpretation of the data. Food Control. (2016) 62:1-9. doi: 10.1016/j.foodcont.2015.10.003

12. Košir IJ, Kocjančič $M$, Ogrinc $N$, Kidrič J. Use of SNIF-NMR and IRMS in combination with chemometric methods for the determination of chaptalisation and geographical origin of wines (the example of Slovenian wines). Anal Chim Acta. (2001) 429:195-206. doi: 10.1016/S0003-2670(00)01301-5

13. Christoph N, Rossmann A, Schlicht C, Voerkelius S. Wine authentication using stable isotope ratio analysis: significance of geographic origin, climate, 
and viticultural parameters. Authentication Food Wine. (2006) 952:16679. doi: 10.1021/bk-2007-0952.ch011

14. Kokkinofta R, Economidou N, Tzioni E, Damianou K, Poulli K, Savvidou $\mathrm{C}$, et al. Studies on the authenticity of local wines by spectroscopic and chemometric analysis. J Chem Chem Eng. (2014) 8:101-7.

15. Cačić J, Renko S, Tratnik M, Gajdoš Kljusurić J, Cačić D, Kovačević D. Wine with geographical indication - awareness of Croatian consumers. Br Food J. (2011) 113:66-77. doi: 10.1108/00070701111097349

16. Lukić I, Horvat I. Differentiation of commercial PDO wines produced in Istria (Croatia) according to variety and harvest year based on HS-SPMEGC/MS volatile aroma compounds profiling. Food Technol Biotechnol. (2017) 55:95-108. doi: 10.17113/ftb.55.01.17.4861

17. Rastija V, Srečnik G, Marica Medić Š. Polyphenolic composition of Croatian wines with different geographical origins. Food Chem. (2009) 115:5460. doi: 10.1016/j.foodchem.2008.11.071

18. Rešetar D, Marchetti-Deschmann M, Allmaier G, Katalinić JP, Kraljević Pavelić S. Matrix assisted laser desorption ionization mass spectrometry linear time-of-flight method for white wine fingerprinting and classification. Food Control. (2016) 64:157-64. doi: 10.1016/j.foodcont.20 15.12 .035

19. Žurga P, Vahčić N, Pasković I, Banović M, Staver MM. Croatian wines from native grape varieties have higher distinct phenolic (nutraceutic) profiles than wines from non-native varieties with the same geographic origin. Chem Biodivers. (2019) 16:e1900218. doi: 10.1002/cbdv.201900218

20. HanŽek M, Sušić G. Croatian wine tourism from the winery perspective: the case of the Grand Cro. In: 4th International Thematic Monograph: Modern Management Tools and Economy of Tourism Sector in Present Era. Belgrade. (2019). p. 669-84.

21. Aghemo C, Albertino A, Gobetto R, Spanna F. Correlation between isotopic and meteorological parameters in Italian wines: a localscale approach. J Sci Food Agric. (2011) 91:2088-94. doi: 10.1002/jsf a. 4510

22. Christoph N, Hermann A, Wachter H. 25 Years authentication of wine with stable isotope analysis in the European Union - Review and outlook. BIO Web Conf. (2015) 5:02020. doi: 10.1051/bioconf/201505 02020

23. Christoph N, Rossmann A, Voerkelius S. Posibilities and limitations of wine authentication using stable isotope and meteorological data, data banks and statistical tests. Part 1: Wines from Franconia and Lake Constance 1992 to 2001. Mitteilungen Klosterneiburg. (2003) 53:23-40.

24. Christoph N, Barátossy G, Kubanović V, Kozina B, Rossmann A, Schlicht C, et al. Possibilities and limitations of wine authentication using stable isotope ratio analysis and traceability. Part 2: Wines from Hungary, Croatia, and other European countries. Mitteilungen Klosterneiburg. (2004) 54:144-58.

25. Philipp C, Horacek M, Nauer S, Reitner H, Rosner A, Jaborek C, et al. Isotope data of Austrian wines: evaluation of their potential as a means of identification of geographic origin and vintage year. Mitt Eilungen Klosterneuburg. (2018) 68:120-40. doi: 10.1155/2018/5123280

26. Geană E-I, Sandru C, Stanciu V, Ionete RE. Elemental profile and $87 \mathrm{Sr} / 86 \mathrm{Sr}$ isotope ratio as fingerprints for geographical traceability of wines: an approach on Romanian Wines. Food Anal Methods. (2016) 10:6373. doi: 10.1007/s12161-016-0550-2

27. Martin GJ, Martin ML. Climatic significance of isotope ratios. Phytochem Rev. (2003) 2:179-90. doi: 10.1023/B:PHYT.0000004187.23624.dd

28. Monakhova YB, Godelmann R, Hermann A, Kuballa T, Cannet C, Schäfer $\mathrm{H}$, et al. Synergistic effect of the simultaneous chemometric analysis of $1 \mathrm{H} \mathrm{NMR} \mathrm{spectroscopic} \mathrm{and} \mathrm{stable} \mathrm{isotope} \mathrm{(SNIF-NMR,} \mathrm{18O,} \mathrm{13C)}$ data: application to wine analysis. Anal Chim Acta. (2014) 833:2939. doi: 10.1016/j.aca.2014.05.005

29. Almeida CM, Vasconcelos MTSD. ICP-MS determination of strontium isotope ratio in wine in order to be used as a fingerprint of its regional origin. J Anal Atomic Spectrom. (2001) 16:607-11. doi: 10.1039/b10 $0307 \mathrm{k}$

30. Almeida CMR, Vasconcelos MTSD. Multielement composition of wines and their precursors including provenance soil and their potentialities as fingerprints of wine origin. J Agric Food Chem. (2003) 51:478898. doi: $10.1021 / \mathrm{jf} 034145 \mathrm{~b}$
31. Coetzee PP, van Jaarsveld FP, Vanhaecke F. Intraregional classification of wine via ICP-MS elemental fingerprinting. Food Chem. (2014) 164:48592. doi: 10.1016/j.foodchem.2014.05.027

32. Cabrita MJ, Martins N, Barrulas P, Garcia R, Dias CB, Pérez-Álvarez EP, et al. Multi-element composition of red, white and palhete amphora wines from Alentejo by ICPMS. Food Control. (2018) 92:80-5. doi: 10.1016/j.foodcont.2018. 04.041

33. Rodrigues SM, Otero M, Alves AA, Coimbra J, Coimbra MA, Pereira E, et al. Elemental analysis for categorization of wines and authentication of their certified brand of origin. J Food Compos Anal. (2011) 24:54862. doi: $10.1016 /$ j.jfca.2010.12.003

34. di Martino M, Domenico C, di Giacomo F, Civitarese C, Cichelli A. ICP-MS analysis for the characterization of the origins of wines. Agro Food Ind Hi Tech. (2013) 24:30-4.

35. Galgano F, Favati F, Caruso M, Scarpa T, Palma A. Analysis of trace elements in southern Italian wines and their classification according to provenance. $L W T$ Food Sci Technol. (2008) 41:1808-15. doi: 10.1016/j.lwt.2008.01.015

36. Suhaj M, Korenovská M. Distribution of selected elements as wine origin markers in the wine-making products. Czech J Food Sci. (2006) 24:23240. doi: 10.17221/3319-CJFS

37. Kruzlicova D, Fiket Ž, Kniewald G. Classification of Croatian wine varieties using multivariate analysis of data obtained by high resolution ICP-MS analysis. Food Res Int. (2013) 54:621-6. doi: 10.1016/j.foodres.2013.07.053

38. Leder R, Kubanović V, Petric I V, Vahčić N, Banović M. Chemometric prediction of the geographical origin of Croatian wines through their elemental profiles. J Food Nutr Res. (2015) 54:229-38.

39. García-Rodríguez G, Hernández-Moreno D, Soler F, Pérez-López M. Characterization of "Ribera del Guadiana" and "Méntrida" Spanish red wines by chemometric techniques based on their mineral contents. J Food Nutr Res. (2011) 50:41-9.

40. Gonzálvez A, Llorens A, Cervera ML, Armenta S, de la Guardia M. Elemental fingerprint of wines from the protected designation of origin Valencia. Food Chem. (2009) 112:26-34. doi: 10.1016/j.foodchem.2008. 05.043

41. Paneque P, Álvarez-Sotomayor MT, Clavijo A, Gómez IA. Metal content in southern Spain wines and their classification according to origin and ageing. Microchem J. (2010) 94:175-9. doi: 10.1016/j.microc.2009.10.017

42. Geana EI, Marinescu A, Iordache AM, Sandru C, Ionete RE, Bala C. Differentiation of Romanian wines on geographical origin and wine variety by elemental composition and phenolic components. Food Anal Methods. (2014) 7:2064-74. doi: 10.1007/s12161-014-9846-2

43. Durdić S, Pantelić M, Trifković J, Vukojević V, Natić M, Tešić Ž, et al. Elemental composition as a tool for the assessment of type, seasonal variability, and geographical origin of wine and its contribution to daily elemental intake. RSC $A d v$. (2017) 7:2151-62. doi: 10.1039/C6RA $25105 \mathrm{~F}$

44. Ivanova-Petropulos V, Wiltsche $H$, Stafilov $T$, Stefova $M$, Motter $H$, Lankmayr E. Multielement analysis of Macedonian wines by inductively coupled plasma-mass spectrometry (ICP-MS) and inductively coupled plasma-optical emission spectrometry (ICP-OES) for their classification. Macedonian J Chem Chem Eng. (2013) 322:265-81. doi: 10.20450/mjcce. 2013.447

45. Vystavna Y, Rushenko L, Diadin D, Klymenko O, Klymenko M. Trace metals in wine and vineyard environment in southern Ukraine. Food Chem. (2014) 146:339-44. doi: 10.1016/j.foodchem.2013.09.091

46. Sen I, Tokatli F. Characterization and classification of Turkish wines based on elemental composition. Am J Enol Viticult. (2013) 65:13442. doi: 10.5344/ajev.2013.13081

47. Fabani MP, Arrúa RC, Vázquez F, Diaz MP, Baroni MV, Wunderlin DA. Evaluation of elemental profile coupled to chemometrics to assess the geographical origin of Argentinean wines. Food Chem. (2010) 119:3729. doi: 10.1016/j.foodchem.2009.05.085

48. Minnaar PP, Rohwer ER, Booyse M. Investigating the use of element analysis for differentiation between the geographic origins of western Cape wines. S Afr J Enol Viticult. (2005) 26:95-105. doi: 10.21548/2 6-2-2124 
49. van der Linde G, Fischer JL, Coetzee PP. Multi-element analysis of South African wines and their provenance soils by ICP-MS and their classification according to geographical origin using multivariate statistics. S Afr J Enol Viticult. (2010) 31:143-53. doi: 10.21548/31-2-1411

50. da Costa NL, Ximenez JPB, Rodrigues JL, Barbosa F, Barbosa R. Characterization of Cabernet Sauvignon wines from California: determination of origin based on ICP-MS analysis and machine learning techniques. Eur Food Res Technol. (2020) 246:1193205. doi: 10.1007/s00217-020-03480-5

51. Martin GJ, Mazure M, Jouitteau C, Martin YL, Aguile L, Allain P. Characterization of the Geographic Origin of Bordeaux Wines by a Combined Use of Isotopic and Trace Element Measurements. American Journal of Enology and Viticulture. (1999) 50:409-17.

52. Gremaud Gr, Quaile S, Piantini U, Pfammatter E, Corvi C. Characterization of Swiss vineyards using isotopic data in combination with trace elements and classical parameters. Eur Food Res Technol. (2004) 219:97104. doi: 10.1007/s00217-004-0919-0

53. Dinca OR, Ionete RE, Costinel D, Geana IE, Popescu R, Stefanescu I, et al. Regional and vintage discrimination of romanian wines based on elemental and isotopic fingerprinting. Food Anal Methods. (2016) 9:240617. doi: 10.1007/s12161-016-0404-y

54. Roca P, Horacek M, Hola M, Tobolkova B, Kolar K, Vaculovic T, et al. Investigation of geographic origin of wine from border regions: results from investigation of two vintages. BIO Web Conf. (2019) 15:02039. doi: 10.1051/bioconf/20191502039

55. Di Paola-Naranjo RD, Baroni MaV, Podio NS, Rubinstein HcR, Fabani MaP, Badini RlG, et al. Fingerprints for main varieties of Argentinean wines: terroir differentiation by inorganic, organic, and stable isotopic analyses coupled to chemometrics. J Agric Food Chem. (2011) 59:7854-65. doi: 10.1021/jf200 7419

56. Dutra SV, Adami L, Marcon AR, Carnieli GJ, Roani CA, Spinelli FR, et al. Characterization of wines according the geographical origin by analysis of isotopes and minerals and the influence of harvest on the isotope values. Food Chem. (2013) 141:2148-53. doi: 10.1016/j.foodchem.2013.04.106

57. Fan S, Zhong Q, Gao H, Wang D, Li G, Huang Z. Elemental profile and oxygen isotope ratio $(\delta 18 \mathrm{O})$ for verifying the geographical origin of Chinese wines. J Food Drug Anal. (2018) 26:1033-44. doi: 10.1016/j.jfda.2017. 12.009

58. Orellana S, Johansen AM, Gazis C. Geographic classification of U.S. Washington State wines using elemental and water isotope composition. Food Chem X. (2019) 1:100007. doi: 10.1016/j.fochx.2019.100007

59. Fiket Ž, Mikac N, Kniewald G. Arsenic and other trace elements in wines of eastern Croatia. Food Chem. (2011) 126:9417. doi: 10.1016/j.foodchem.2010.11.091

60. Winkler AJ, Cook JA, Kliewer WM, Lider LA. Climate and soils. In: Cerruti L, editor. General Viticulture, 2nd ed. Berkeley, CA: University of California Press (1974). p. 710.

61. Law on wine. Narodne Novine. (2019) 32/2019.

62. eAmbrosia - The EU Geographical Indications Register. Available online at: https://ec.europa.eu/info/food-farming-fisheries/food-safety-and-quality/ certification/quality-labels/geographical-indications-register (Accessed December 5, 2020).

63. Regulation (EU) No 1308/2013 of the European Parliament and of the Council. Establishing a Common Organisation of the Markets in Agricultural Products and Repealing Council Regulations (EEC) No 922/72, (EEC) No 234/79, (EC) No 1037/2001 and (EC) No 1234/2007. Official Journal of the European Communities, L 347/671 (2013).

64. Commission Delegated Regulation (EU) 2018/273. Supplementing Regulation (EU) No 1308/2013 of the European Parliament and of the Council as Regards the Scheme of Authorisations for Vine Plantings, the Vineyard Register, Accompanying Documents and Certification, the Inward and Outward Register, Compulsory Declarations, Notifications and Publication of Notified Information, and Supplementing Regulation (EU) No 1306/2013 of the European Parliament and of the Council as Regards the Relevant Checks and Penalties, Amending Commission Regulations (EC) No 555/2008, (EC) No $606 / 2009$ and (EC) No 607/2009 and repealing Commission Regulation (EC) No 436/2009 and Commission Delegated Regulation (EU) 2015/560. Office Journal of the European Communities, L 58/1 (2017).
65. Commission Implementing Regulation (EU) 2018/274. Laying Down Rules for the Application of Regulation (EU) No 1308/2013 of the European Parliament and of the Council as Regards the Scheme of Authorisations for Vine Plantings, Certification, the Inward and Outward Register, Compulsory Declarations and Notifications, and of Regulation (EU) No 1306/2013 of the European Parliament and of the Council as Regards the Relevant Checks, and Repealing Commission Implementing Regulation (EU) 2015/561. Office Journal of the European Communities L 58/60 (2017).

66. Benes RPJ, Reininger F, del Bianco A (inventors). Method for the Spectroscopic Determination of Ethanol Concentration in an Aqueous Sample. DE patent EP1073896, European Patent Office, Vienna.

67. International Organisation of Vine and Wine (OIV). Compendium of International Methods of Analysis of Wines and Musts. Paris (2019).

68. Miloš M, Petric I V, Jusup J, Šimon S, Leder R, Banović M. Preparation of wine for the analysis by analytical techniques: NMR, IRMS and ICP-OES - method validation. In: Proceedings of 9th International Congress of Food Technologists, Biotechnologists and Nutritionists. Zagreb. (2018). p. 103-7.

69. Larcher R, Nicolini G. Survey of 22 mineral elements in wines from Trentino (Italy) using ICP-OES. Ital J Food Sci. (2001) 13:233-41.

70. Magnusson B, Örnemark U (eds.). Eurachem Guide: The Fitness for Purpose of Analytical Methods - A Laboratory Guide to Method Validation and Related Topics, 2nd edn. Eurachem (2014).

71. Ellison SLR, Williams A (eds.). Eurachem/CITAC Guide: Quantifying Uncertainty in Analytical Measurement, 3rd edn. Teddington (2012).

72. International Standard ISO 17025:2017. General Requirements for the Competence of Testing and Calibration Laboratories (ISO/IEC 17025:2017; EN ISO/IEC 17025:2017). Croatian Standards Institute, HRN EN ISO/IEC 17025:2017 hr,en HR:73 (en: 34) (2019).

73. USEPA. Data Quality Assessment: Statistical Methods for Practitioners. EPA QA/G-9S. EPA/240/B-06/003 February 2006. Office of Environmental Information, US Environmental Protection Agency, Washington, DC (2006). $190 \mathrm{p}$.

74. Galani-Nikolakaki S, Kallithrakas-Kontos N, Katsanos AA. Trace element analysis of Cretan wines and wine products. Sci Total Environ. (2002) 285:155-63. doi: 10.1016/S0048-9697(01)00912-3

75. Tariba B. Metals in wine-impact on wine quality and health outcomes. Biol Trace Elem Res. (2011) 144:143-56. doi: 10.1007/s12011-011-9052-7

76. OIV Code Sheet, Issue 2015/01. International Code of Oenological Practices.

77. European Food Safety Authority. Dietary Reference Values for nutrients Summary report. EFSA Support Publ. (2017) 14:e15121. doi: 10.2903/sp.efsa.2017.e15121

78. Charlton AJ, Wrobel MS, Stanimirova I, Daszykowski M, Grundy HH, Walczak B. Multivariate discrimination of wines with respect to their grape varieties and vintages. Eur Food Res Technol. (2010) 231:73343. doi: 10.1007/s00217-010-1299-2

79. Croatian Meteorological and Hydrological Service. Climate Data of Croatia. Annual Report (2015). Available online at: https://meteo.hr/klima_e.php? section=klima_podaci\&param $=\mathrm{k} 2 \_1 \&$ Godina $=2015$ (accessed May 28, 2020).

80. Croatian Meteorological and Hydrological Service. Climate Data of Croatia. Annual Report (2016). Available online at: https://meteo.hr/klima_e.php? section=klima_podaci\&param $=\mathrm{k} 2 \_1 \&$ Godina $=2016$ (accessed May 28, 2020).

81. Farquhar GD, Ehleringer JR, Hubick KT. Carbon isotope discrimination and photosynthesis. Annu Rev Plant Physiol Plant Mol Biol. (1989) 40:50337. doi: 10.1146/annurev.pp.40.060189.002443

82. Gilbert A, Silvestre V, Segebarth N, Tcherkez G, Guillou C, Robins RJ, et al. The intramolecular 13C-distribution in ethanol reveals the influence of the $\mathrm{CO}_{2}$-fixation pathway and environmental conditions on the sitespecific 13C variation in glucose. Plant Cell Environ. (2011) 34:110412. doi: 10.1111/j.1365-3040.2011.02308.x

83. Geana I, Iordache A, Ionete R, Marinescu A, Ranca A, Culea M. Geographical origin identification of Romanian wines by ICP-MS elemental analysis. Food Chem. (2013) 138:1125-34. doi: 10.1016/j.foodchem.2012.11.104

84. Oroian M. Romanian white wine authentication based on mineral content. $J$ Agroaliment Process Technol. (2015) 21:9-13.

85. Tanabe CK, Nelson J, Boulton RB, Ebeler SE, Hopfer H. The use of macro, micro, and trace elemental profiles to differentiate commercial single vineyard pinot noir wines at a sub-regional level. Molecules. (2020) 25:2552. doi: $10.3390 /$ molecules 25112552 
86. Pérez Trujillo JP, Conde JE, Pérez Pont ML, Câmara J, Marques JC. Content in metallic ions of wines from the Madeira and Azores archipelagos. Food Chem. (2011) 124:533-7. doi: 10.1016/j.foodchem.2010.06.065

87. Frías S, Pérez Trujillo JP, Peña EM, Conde JE. Classification and differentiation of bottled sweet wines of Canary Islands (Spain) by their metallic content. Eur Food Res Technol. (2001) 213:145-9. doi: 10.1007/s002170100344

88. Álvarez M, Moreno IM, Jos Á, Cameán AM, Gustavo González A. Differentiation of 'two Andalusian DO 'fino' wines according to their metal content from ICP-OES by using supervised pattern recognition methods. Microchem J. (2007) 87:72-6. doi: 10.1016/j.microc.2007.05.007

89. Batukaev A, Magomadov A, Sushkova S, Minkina T, Bauer T. Influence of boron fertilization on productivity of grape plants. BIO Web Conf. (2016) 7:01030. doi: 10.1051/bioconf/20160701030

90. Catarino S, Madeira M, Monteiro F, Rocha F, Curvelo-Garcia AS, de Sousa RB. Effect of bentonite characteristics on the elemental composition of wine. $J$ Agric Food Chem. (2008) 56:158-65. doi: 10.1021/jf0720180

91. Kment P, Mihaljevič M, Ettler V, Šebek O, Strnad L, Rohlová L. Differentiation of Czech wines using multielement composition - a comparison with vineyard soil. Food Chem. (2005) 91:157-65. doi: 10.1016/j.foodchem.2004.06.010

92. Karoglan M, Telišman Prtenjak M, Šimon S, Osrečak M, Anić $M$, Karoglan Kontić J, et al. Classification of Croatian winegrowing regions based on bioclimatic indices. E3S Web Conf. (2018) 50:01032. doi: 10.1051/e3sconf/20185001032
93. Omazić B, Telišman Prtenjak M, Prša I, Belušić Vozila A, Vučetić V, Karoglan $\mathrm{M}$, et al. Climate change impacts on viticulture in Croatia: viticultural zoning and future potential. Int J Climatol. (2020) 40:5634-55. doi: 10.1002/ joc. 6541

Conflict of Interest: JJ was employed by Department of Physico-Chemical Testing, Center for Viticulture, Enology and Edible Oils Analysis, Croatian Agency Agriculture and Food, Zagreb, Croatia, during the research and as she performed the ICP-OES analyses. After the experimental part of the research was finished, she changed her job and her current employment is at company Primevigilance d.o.o., Zagreb, Croatia.

The remaining authors declare that the research was conducted in the absence of any commercial or financial relationships that could be construed as a potential conflict of interest.

Copyright (c) 2021 Leder, Petric, Jusup and Banović. This is an open-access article distributed under the terms of the Creative Commons Attribution License (CC BY).

The use, distribution or reproduction in other forums is permitted, provided the original author(s) and the copyright owner(s) are credited and that the original publication in this journal is cited, in accordance with accepted academic practice. No use, distribution or reproduction is permitted which does not comply with these terms. 